\title{
1
}

\section{The Global Greyfields Transition: Why Urban Redevelopment in Low-Density, Car-Based Middle Suburbs Needs a New Model}

\section{Introduction}

This book introduces greyfield precinct regeneration (GPR), a set of new urban-planning models capable of regenerative medium-density redevelopment in ageing, established, well-located, low-density middle-ring suburbs of large, fast-growing cities that are primarily residential: the greyfields (Box 1.1). Greyfields are areas where the value of built assets now lies primarily in the land rather than in the ageing buildings. The attraction of the middle suburbs is that they are generally well served with local services, facilities, and community groups built over several decades. However, they lack sufficient new housing supply to meet the demand for well-located, diverse, twenty-first-century housing, especially in large, fast-growing cities.

There are two categories of GPR models: place-activated and transit-activated.

1. Place-activated GPR targets residential precincts in the middle suburbs with high redevelopment potential due to their attractive locational

The original version of the chapter has been revised. A correction to this chapter can be found at https://doi.org/10.1007/978-981-16-6238-6_9 
values such as proximity to schools, health services, and parks, but in need of reactivation to meet twenty-first-century needs. They need housing and neighbourhood regeneration with new eco-infrastructures for energy, water, waste, transit, and communications, all providing better services with a reduced ecological footprint, but require higher densities and more variety of dwelling types and sizes for the market to work. They are the 'missing middle' of urban renewal: medium density at precinct scale.

2. Transit-activated GPR injects new transit along corridors that enable GPR precincts to be created like pearls along a string of tram or major road corridors, together with activated personal mobility systems. This kind of GPR offers similar place-based attractions, but its biggest value lies in its potential to be part of a much more accessible transit service for destinations across the car-dependent greyfields and their centres of urban activity, as well as having local micro-mobility (electric bikes, scooters, skateboards, and shuttles) providing networks and services that link station precincts to their catchments. This model is developed in the book around new forms of mid-tier transit, especially trackless trams, capable of initiating a transition from primarily car-dependent suburbs.

In combination, these two models provide transition pathways to more sustainable, liveable, and regenerative twenty-first-century urban development.

Middle suburbs are the focus of the book, as urban regeneration of central and inner areas (particularly in CBDs and brownfields) has been more advanced over the past 25 years in Australian and North American cities after decades of inner-city decline (Box 1.1). However, this growth has not been able to move into middle suburbs in either Australia or North America due largely to zoning and land-assembly issues. Innerarea regeneration has been able to successfully focus on large precincts that consisted of abandoned industrial or warehousing districts or outmoded commercial buildings, often with single property owners, making it easier for developers to create precinct-scale projects. Meanwhile, outer 
suburbs have continued to grow as low-density, car-dependent, precinctscale greenfield developments, based on large blocks of subdivided rural land. Attempts to increase supply of new housing in the middle suburbs using precinct-scale 'growth' zoning of activity centres and major transport corridors have not proven to be sufficient magnets for residential property developers, as these suburbs have a myriad of individual property owners, making precinct-scale developments very difficult. The only model so far demonstrated to attract significant housing redevelopment in these greyfield areas is subdivision of single lots into micro-lots that have a ready market but do not provide the additional benefits and common-good outcomes due to their small scale (outlined in Box 1.1 and in detail in this book). Therefore, the new GPR model in both placeactivated and transit-activated forms is based on multiple contiguous lots being assembled into a larger-scale set of opportunities for urban precinct regeneration.

The book will articulate the key planning and design features of these models and why they enable many more common-good outcomes (additionality). A major focus is also on how to deliver the GPR. A significant body of work by architects in recent years has demonstrated what the market should be supplying in such areas-but primarily at building, rather than precinct, scale (as reflected in the 'missing middle' housingdesign competitions recently held in Queensland, NSW, and Victoria). But apart from 'knock-down-rebuild', there has not been a model able to articulate the planning processes necessary for higher-yield regenerative redevelopment in greyfields. Such planning necessitates involvement of multiple stakeholders from government, local communities, and builtenvironment industries developing a common goal and vision for precinct-scale urban regeneration.

GPR models are of particular relevance to the low-density middle suburbs characteristic of Australian cities, where the underpinning research for this book was based. They are equally applicable to cities in the USA, Canada, New Zealand, and parts of Europe that share common urban geographies and urban development challenges (Loader, 2015). 


\section{Box 1.1 The Three Arenas of Urban Development: Greenfields, Brownfields, and Greyfields}

There are three arenas for urban planning and development in twenty-firstcentury cities: greenfields, brownfields, and greyfields (Newton, 2010). Greenfields have been the traditional focus for city growth, with low-density urban development occurring on previously zoned rural-agricultural land on the fringe of existing built-up areas. Compact city strategies have attempted to redirect investment, development, and population inwards and upwards to urban infill, rather than outwards, in an attempt to halt urban sprawl. Infill here refers to the process of redeveloping existing ageing built properties, usually at a higher density/yield and sometimes different use. Infill can occur on both brownfield and greyfield sites, but the development models and processes (involving planning, urban design, finance, construction, and community engagement), and the built-environment outcomes resulting from each, are distinctly different (Newton \& Glackin, 2014).

Brownfield redevelopment has emerged as a process for re-imagining and transitioning those parts of cities that have 'outlived' their original industrial-era functions. Principal among these are the abandoned or under-used docklands that now occupy prime waterfront sites in all coastal cities, as well as the thousands of industrial-era manufacturing sites in large metropolitan areas. They can be distinguished from greyfield development sites in several key respects: they are typically owned by a single party, usually government or industry; they are of a scale closer to that provided by greenfield sites for development; they are contaminated to some degree, depending on the previous use; and they are usually unoccupied, obviating the need for community engagement at a level required of greyfields. As such, brownfield sites have been attractive to both governments and the property development and finance industries that have been able to create a development model to undertake such projects (Newton \& Thomson, 2017).

Greyfields redevelopment has proven to be more challenging. 'Greyfields' is a term used to describe the extensive band of ageing, occupied, residential tracts of inner and middle suburbs that are physically, technologically, and environmentally obsolescent, and which represent economically outdated, failing, or under-capitalised real-estate assets. They typically occur in a 5-25 km radius from the centre of large cities and are rich in services, transport, amenities, and employment compared to the outer and peri-urban (greenfield) suburbs (Newton, 2010). This is the reason they have become a key target for more intensive redevelopment by government planning agencies in their future metro strategies. Current planning strategies are failing to deliver the scale and quality of urban infill in the greyfields, however. Small-scale, piecemeal, fragmented, suboptimal small-lot subdivision is spreading like a virus through greyfield suburbs with high redevelopment potential, removing up to $50 \%$ of private green space and blocking prospects for better designed, regenerative, precinct-scale, medium-density 'missing middle' redevelopment (Newton et al., 2020; Newman \& Kenworthy, 2015). Developing new models and processes for precinct-scale regeneration in greyfields has been the catalyst for the research behind this book, guided by urban transition theory, concepts, and processes. 
GPR (both place-activated and transit-activated) represents niche innovation capable of being incorporated into current metropolitan planning strategies and instruments designed to deliver more compact, full-service districts (i.e., with the accessibility and amenities of most inner urban areas) by focusing on urban infill rather than greenfield development. Greenfield-based planning strategies are currently proving difficult to implement in a sustainable way because infrastructure and service provision in low-density environments is expensive, and these areas are typically lacking in employment opportunities and thus depend heavily on car-based commutes. GPR offers a better solution for remaking twentyfirst-century cities, as it can provide more integrated land use and transport planning capable of delivering critical environmental, economic, and social outcomes that respond to a common set of national performance goals for cities: sustainable, liveable, inclusive, resilient, and productive. Transit-activated GPR can integrate land redevelopment with a focus on new transit along main roads and provide links into surrounding areas through 'last mile' local micro-mobility services. Place-activated GPR targets neighbourhoods with high redevelopment potential that integrate high-quality local micro-mobility infrastructures as well as longer services to reach the nearest major transit service. Both GPR models share the need for new planning approaches, with place-activated GPR not likely to attract as much density as in the precincts surrounding transit-activated GPR stations along a whole regenerated corridor.

Such reduced car dependence and increased residential density and land-use mix can often be seen as disruptive to the status quo of many affected residential communities and can thus face resistance in the absence of a clearly demonstrated ability of a GPR project to deliver community additionality. Much of the greyfields redevelopment to date has generated more housing and car traffic in the middle suburbs without any environmental or local amenity benefits: a reason why local residents adopt a NIMBY ('not in my backyard') stance. In this context, our use of the term 'additionality' refers to those attributes of neighbourhood regenerative redevelopment that need to accompany medium-density redevelopment; for example, zero-carbon energy, water-sensitive design and integrated water systems, improved mobility, social infrastructure, and enhanced green space-delivering multiple, measurable benefits to the 
local community. Thus, the additionality of GPR is designed to achieve much more than business-as-usual redevelopment. This book emphasises the new planning, design, and engagement processes required to demonstrate how these additionality benefits can become upfront requirements in GPR.

This chapter and those that follow provide a roadmap for reducing risk as well as promoting the benefits of GPR interventions. They address the multiple and well-established challenges facing large, fast-growing cities:

- Car-dependent sprawl - the multiple negative externalities of sprawl (increased carbon footprints, increased suburbanisation of social disadvantage, reduced access to jobs and services, increased commute times).

- Housing diversity - supplying the right mix of new and affordable housing in the right places.

- Re-localisation - the arrival of the COVID-19 pandemic has highlighted the need for cities to re-localise their urban structures, reflecting the increased importance and greater demand for local districts and neighbourhoods - precincts — that are more self-sufficient and are capable of supporting increased home-based work, walkability, local greening, and the multiple benefits of 20-minute neighbourhoods.

The next section sets out the 10 core transitions that will be addressed in this book and how they will be explored. Each examines the multiple innovation arenas in which change needs to happen to deliver moresustainable urban development in the twenty-first century.

\section{The 10 Transitions in Greening the Greyfields}

City development patterns have evolved over time in response to radically different transport and building technologies, changing locational workplace-residence requirements during different industrial and economic eras, and the city development strategies of influential regimes comprising metropolitan governments and the property industry. A 
critical transition challenge that now arises is overcoming the inertia and tensions associated with the inflexible nature of many features of the current built environments to achieve a common set of goals for twentyfirst-century cities: sustainable, liveable, inclusive, resilient, and productive. The following sections briefly outline these features and their shortcomings, identify what needs to change, and describe how they will be covered in the book. The first five transitions are related to current built-environment and planning systems and how they vary over time and across cities. The second five concern sustainable urban development transitions and the case for more-compact cities and precinct-scale interventions in greyfields.

\subsection{Transition 1: Urban Fabrics}

Urban fabric is a shorthand term for the physical built environment patterns that have resulted from different underlying transport infrastructures supporting average journey-to-work travel times of approximately 30 minutes (the 'Marchetti anthropological constant') from agricultural eras to the present. The Theory of Urban Fabrics (Newman et al., 2016) reveals three dominant city types from history: walking cities, transit cities, and automobile cities. Most cities today have a mixture of all three urban fabrics (Fig. 1.1).

Walking cities are dense, mixed-use areas of generally more than 100 persons per hectare. The oldest urban typology, it dominated until the 1850s. Many modern cities are built around a nucleus of an older walking city, but they struggle to retain the walking urban fabric due to the competing automobile-city fabric that now overlies it. Reacting to this competition, many modern cities are now attempting to reclaim the dense, fine-grained street patterns associated with walkability.

Transit cities are extensions of the old walking city made possible by the introduction of trains and, later, trams between 1850 and 1950. Trams and trains supported corridor development with typical densities between 35 and 100 persons per hectare, with higher-density walking fabric around transit stops. The increased speed of transit allowed urban development to extend $20 \mathrm{~km}$ or more from the city centre. 


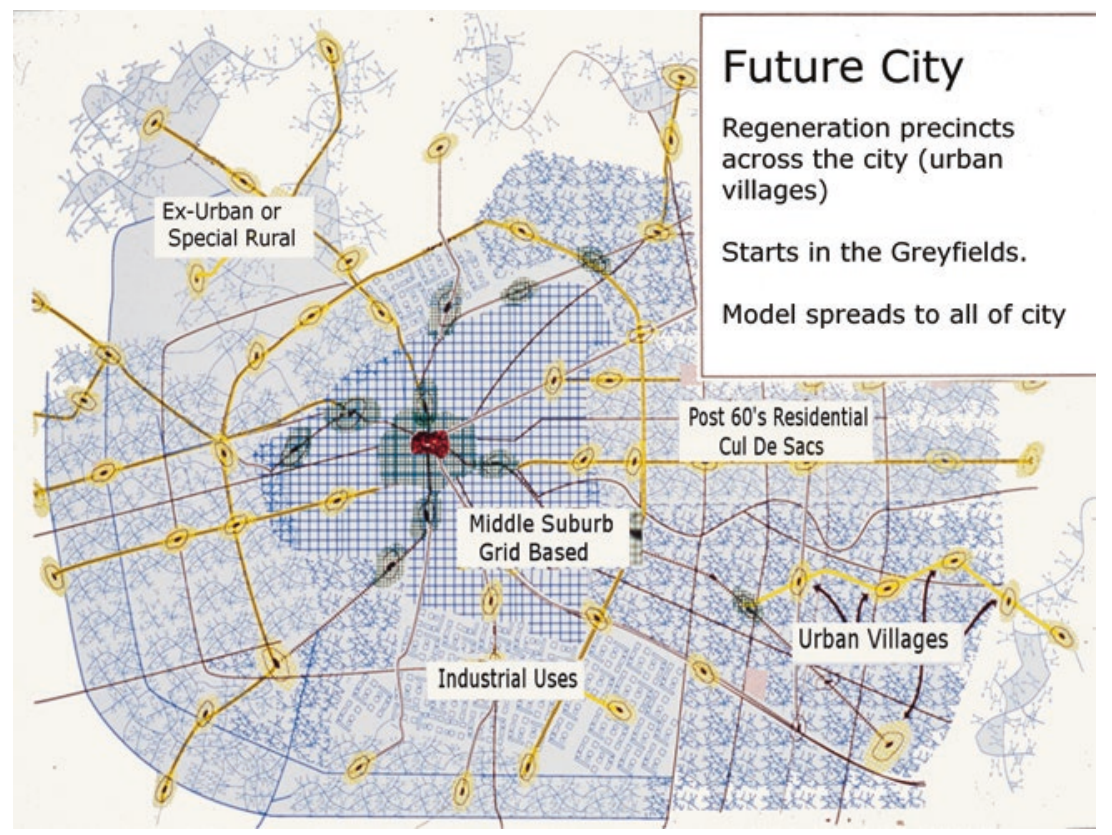

Fig. 1.1 Automobile city, transit city, and walking city-a mix of three city fabrics. (Source: Newman \& Kenworthy, 2015)

Automobile cities emerged from the 1950s onwards with the advent of mass automobile production. Once there was individualised motor transport, city growth was no longer constrained to fixed rail corridors. In these new kinds of cities, population densities fell to less than 35 persons per hectare (low-density sprawl) because the flexibility and speed of cars (average $50-80 \mathrm{~km} / \mathrm{h}$ on uncongested roads) allowed residents to live well beyond a $20 \mathrm{~km}$ radius from the city centre. The term 'automobile dependence' was developed in the 1980s to express how cities were increasingly being built around the car, leading to a multitude of issues that are now getting beyond the control of most planning systems (Newman \& Kenworthy, 1989).

A fundamental problem with mid- to late-twentieth-century town planning has been the belief that there is only one type of city-the automobile city - and town planning regulations have been formulated to 
deliver that. This is notwithstanding the fact that the negative aspects of designing cities predominantly for automobile use have become increasingly apparent and have constituted a failure of urban policy and planning. This book addresses that fundamental issue by suggesting the need for a specific and place-based focus on a new kind of fabric in the middle suburbs.

A forced transition to telecommuting during COVID-19 has raised questions about the prospects of a shift in regime from the daily work commute to one that is more flexible and weekly for many, thereby challenging Marchetti's long-operating anthropocentric travel-time constant (linked to an average 30-minute travel-time budget) that has shaped transport-land use relationships and changes over centuries. The importance of each fabric is more than likely going to continue, with face-toface urbanity supported by electronic interactions (Florida, 2017). But the need for re-localisation around new centres or precincts is bound to be a new focus for many reasons (Fig. 1.1).

Transition 1 Retrofit automobile-dependent suburbs with walkingcity and transit-city transport infrastructures at higher levels of residential redevelopment (a focus of Chap. 4).

\subsection{Transition 2: Building Typologies}

The urban landscape of large cities reveals three building forms or typologies: high rise, medium density, and detached low density. Each represents different urban qualities and can equally accommodate the requirements for a particular urban form and level of urban density at a precinct scale, depending on spacing and type of building (UrbiumEtOrbi, 2015). For low-density 'suburban' cities, detached housing has represented the dominant mode for accommodating resident populations, and continues to do so for many countries such as Australia, although the percentage share is slowly declining in the capital cities (e.g., in 2016, 

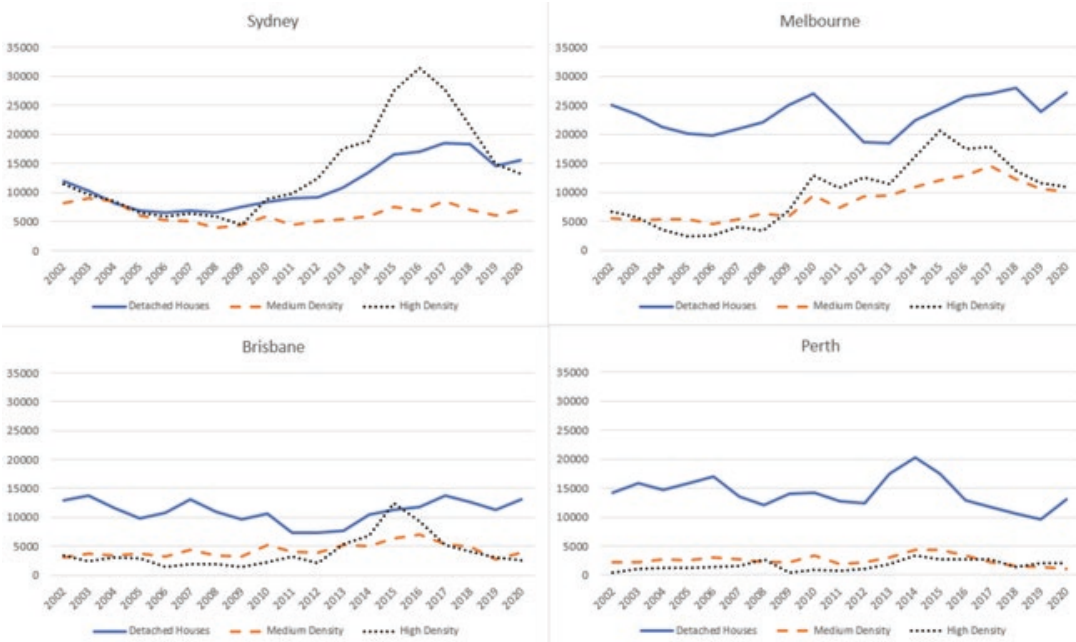

Fig. 1.2 Dwelling approvals 2002-2020 for Australia's major capital cities. (Source: Adapted from Newton et al., 2017)

66\% separate houses, 21\% medium density, and 13\% high-rise apartments; .id, 2018). A suburban-to-urban transition will require the strategic injection of more medium-density and high-rise buildings in established low-density suburban settings where detached housing constituted the original building form from the 1940s on. As discussed in subsequent sections, this will require new models for land assembly and redevelopment in greyfield suburbs.

The pattern of medium-density approvals in Australia's four largest cities (Fig. 1.2) reflects the barriers that this class of development has faced to date in achieving greater take-up: slow recognition by industry of underlying population demand (a focus for Chap. 6); poor urban-design responses, and restrictive government residential zoning policies (a focus in Chap. 7). In the two largest cities with the least-affordable housing, apartment construction has boomed. A comparative analysis of built forms and densities of Australia's three largest cities with Vancouver, Montreal, and London (Spencer et al., 2015) reveals two contrasting patterns of density distribution (Fig. 1.3). The first urban pattern features extensive areas of low (<50 pph) residential suburban densities with a 


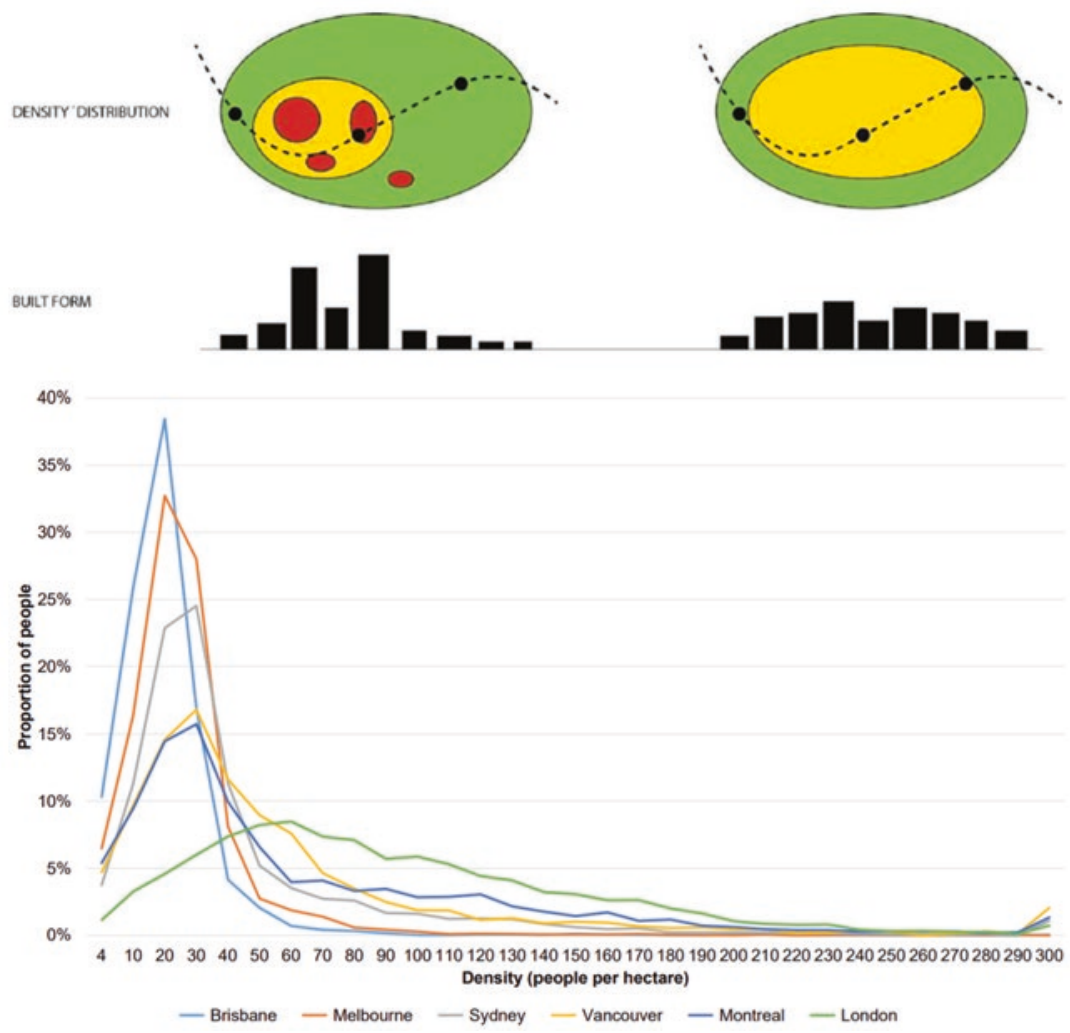

Fig. 1.3 City built-form and density models. (Source: Spencer et al., 2015)

relatively small number of concentrated areas zoned for high-density building (>400 pph) —CBD, major mixed-use activity centres, and transit nodes: effectively the current Australian model. As Woodcock et al. (2010, p. 104) have noted, 'the market has become polarised into fringe suburbs and inner-city towers and there has been a lack of market incentive to innovate at medium density in established suburbs'. The second urban development pattern features a more even distribution of mid-range densities that offers the potential for implementing more cost-effective transit-oriented development versus car-dependent sprawl. Achieving this urban landscape in Australian cities will require redevelopment of established greyfield low-density suburbs capable of 


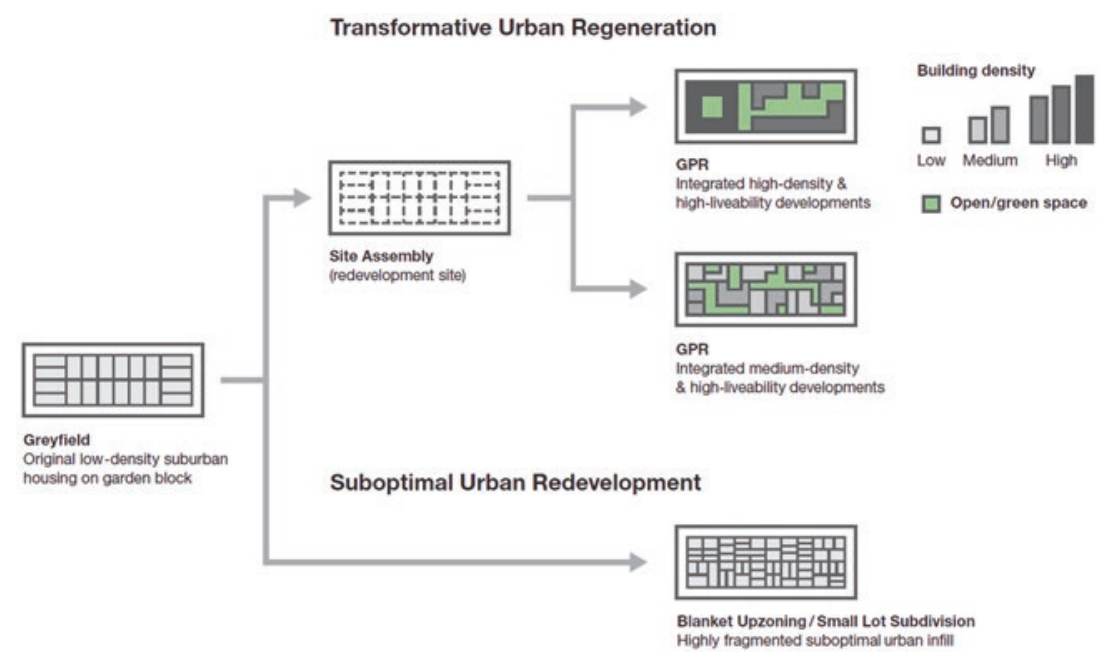

Fig. 1.4 Alternative building typologies and densities for a precinct of common dimensions

transitioning from a model that facilitates suboptimal small-lot subdivision to precinct-scale regeneration involving lot consolidation-a principal focus of this book (Fig. 1.4).

The greatest benefit that urban lot consolidation provides is the enhanced potential for integrated design responses on larger lots compared to the spatial constraints of small lots. Larger assembled parcels of land unlock the potential for transformative urban-design responses. By thinking beyond small individual lots, a step change in reshaping the urban fabric becomes possible; for example, to increase density from individual dwellings on fenced blocks to higher density outcomes with sufficient space to allow for the requisite site arrangement to integrate other aspects that can enhance liveability and sustainability; these can include on-plot open space, building setback for privacy, and retention of existing site features such as trees. These liveability and sustainability benefits will be most successfully achieved through a context-dependent, design-led approach whereby a development proposal is based on meeting pre-established quality criteria, such as urban-precinct design principles.

Current planning practice in most urban areas looks to increase density through blanket up-zoning for small-lot subdivision infill. However, 
this type of redevelopment emphasises site yield over site design quality. Not all density is equal. A development that seeks only site yield will increase overall floor area (and population), but does not necessarily improve urban liveability or sustainability; in other words, additionality-additional benefits for residents and the city collectively. In practice, most blanket up-zoning brings about a reduction in the urban amenity and liveability of an area due to increased car traffic, more noise generation, reduced privacy, loss of greenery, and increased hard surfaces. Such decreases in urban quality can drive NIMBY responses. However, through good design, it becomes possible to address each of these potential issues, to deliver increased urban population density as well as additionality. Good-quality design creates a market 'pull' for more of the same-that is, a well-designed GPR product-whereas poor design outcomes in the form of suboptimal infill that results from blunt policy instruments (such as blanket up-zoning) elicits community resistance. The place-activated GPR process developed for Greening the Greyfields required that additionality become a core concept as well as a demonstrable outcome from any precinct-regeneration project as a necessary condition for changing a NIMBYresponse from residents and local governments in the middle suburbs to YIMBY ('yes, in my back yard') (Fig. 1.5).

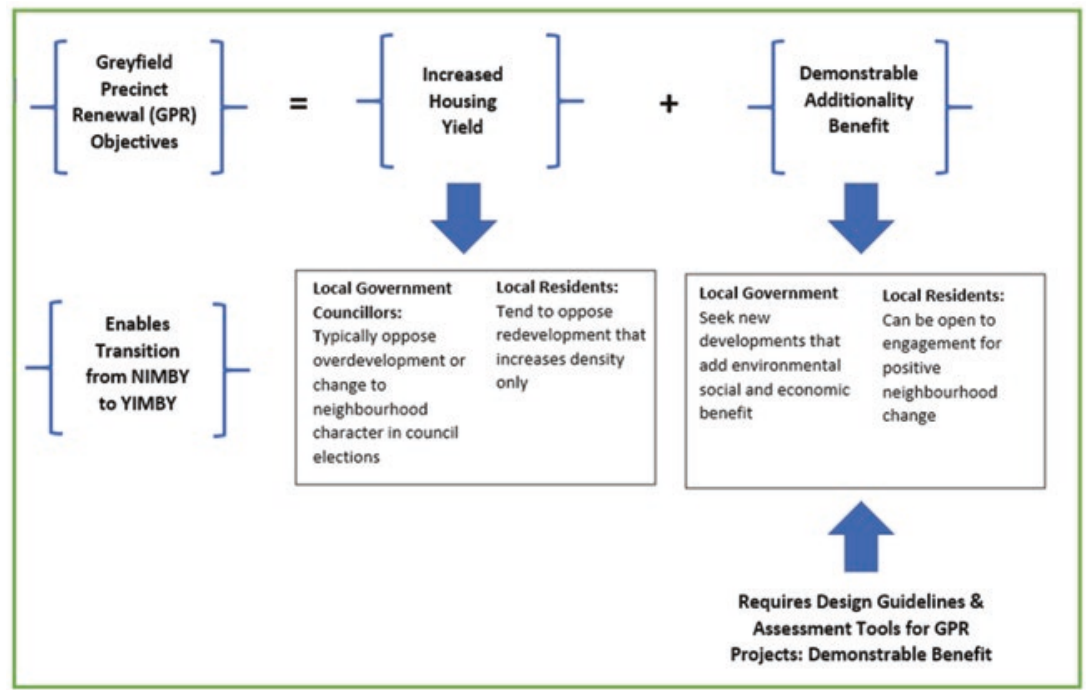

Fig. 1.5 The concept of additionality. (Source: Newton et al., 2020) 
Transition 2 Increase provision for strategically planned and designed high- or medium-density housing in established greyfield suburbs, employing innovative place-activated and transit-activated GPR models for high-liveability outcomes that balance development footprint with green space, in contrast to small-lot subdivisions with suboptimal outcomes (a focus of Chaps. 2, 4, 5, and 7).

\subsection{Transition 3: The Evolving Spatial Patterns of Urban Industrial Cycles}

Most Western countries are now in a post-industrial era of urban development that has witnessed several radical transitions over a relatively short period of time in modern history:

- A transition to the manufacturing city where centripetal forces were dominant in locating industries in key centres where raw materials for the production of goods could be readily shipped and processed in factories powered by fossil fuels (primarily coal). Workers followed the jobs, with significant rural-to-urban migration (an urbanisation process that continues in developing countries to the present). Until the 1950s, the urban fabrics of such centres were indicative of walking and transit cities, and were associated with medium levels of residential and population density.

- A transition to the services city, linked to an increasingly consumerdriven economy after the Second World War, saw rapid growth in private car ownership that supported the powerful centrifugal forces of rapid suburbanisation. For half a century, the 'American model' of urban development dominated city planning, with suburbanisation centred on uniformly zoned, low-density, single-family, car-dependent, detached-housing estates that defined the automobile-city fabric. A powerful regime emerged to support this model: property developers, the automobile and oil industries, housing and road contractors, and city planners. This era was also associated with a depopulation of 
inner-city suburbs as traditional heavy-manufacturing industries began to shift to low-cost regions (often off-shore), creating brownfield sites and 'donut cities', until forces of gentrification and redevelopment linked to a new demographic and a wave of new information industries and workers began to reverse the trend (Brotchie et al., 1987; Newton, 1995) (Fig. 1.6).

- In the twenty-first century, the pendulum has swung from suburbanisation to re-urbanisation, creating pressures on the established areas of cities (CBDs and their surrounding inner and middle suburbs) to accommodate new populations, knowledge-economy industries, and housing. They are the favoured locations for the new growth industries: creative, information, and knowledge-based businesses that require face-to-face interactions. They are also favoured locations for their workforces, creating agglomeration economies that are the engines of contemporary economic development world-wide. They also tend to represent the high residential amenity neighbourhoods in walking and transit areas of cities in developed economies, with superior access to higher education and health services, interactive spaces such as coffee shops, public transport, and jobs. High liveability and employment factors combine to make such urban centres highly attractive for both local populations and overseas-educated, migrant populations, and contribute to sustained levels of population growth

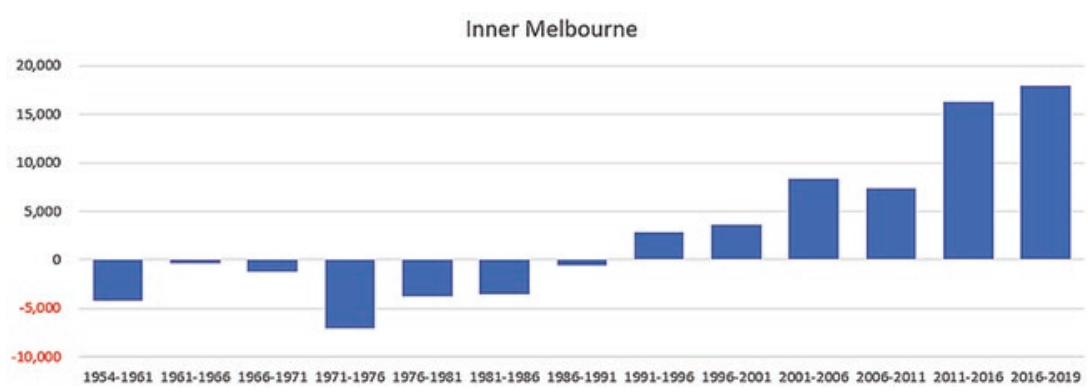

Fig. 1.6 Inner Melbourne-average annual population change revealing eras of depopulation (reflecting early suburbanisation) and repopulation (re-urbanisation). (Source: Victorian Department of Energy Land Water and Planning based on data from the Australian Bureau of Statistics) 
and pressure on city governments where a planning and development deficit is now evident. The fact that restrictive zoning schemes 'lock up' most existing greyfield suburbs from higher-density redevelopment means that greenfield development and suburban sprawl, with their associated negative externalities, continue to be a feature of Australian cities.

Transition 3 Design a metropolitan plan for more-compact cities comprising networks of '20 minute neighbourhoods' connected by transit-activated corridors that connect more full-service districts in an information-based telematic era that can now deliver more sustainable urban development (a focus of Chaps. 2, 3, 4, 5, 6, and 7).

\subsection{Transition 4: Housing Life Cycles and Residential Redevelopment}

Achieving the compact city via suburban re-urbanisation will depend upon both a significant increase in the supply of redevelopable land in brownfields and greyfields and the way they are retrofitted. Brownfield sites are more readily identifiable and redevelopable at precinct scale. More challenging is assessing residential redevelopment potential in greyfields. A first-level analysis in what is a multi-criteria exercise involves calculating a residential redevelopment potential index (RPI) that indicates the proportion of a property's value attributable to the land as distinct from the built asset (RPI = land value/total property value; where an index value of 1.0 indicates that all value is in the land). As Fig. 1.7 shows, using municipal rating data for each property across a city reveals a clear housing life cycle for each district (suburb or local government area), ranging from youthful (in outer suburbs with a concentration of new residential subdivisions), to maturing (the middle suburbs) to regenerating (where a significant level of new infill housing development is occurring as remaining stock continues to decline physically, technologically, and environmentally). 


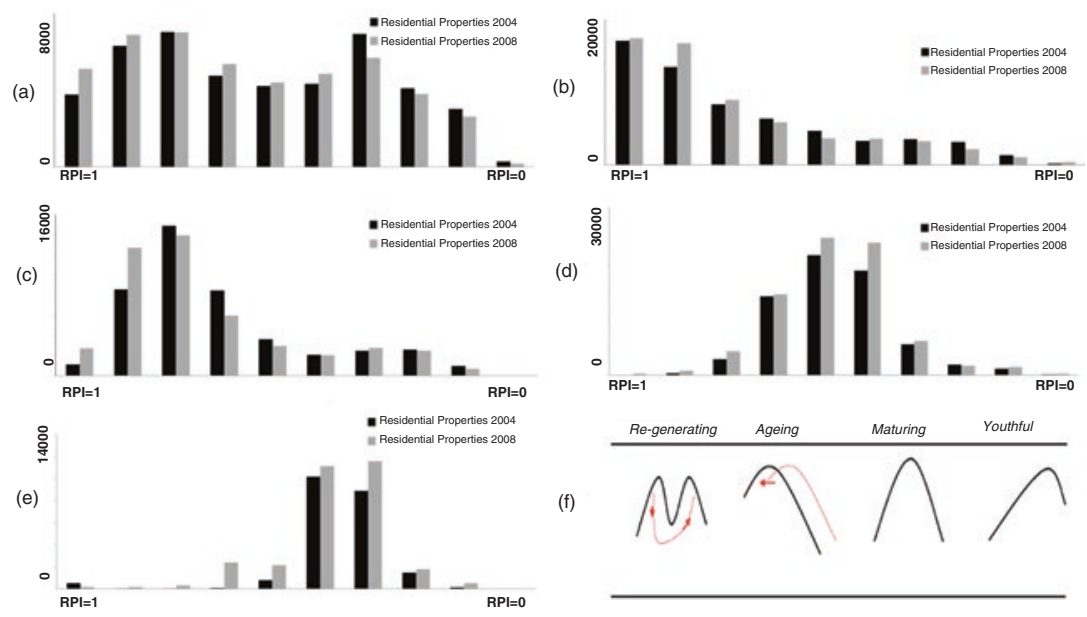

Fig. 1.7 Stages in the housing life cycle across a metropolitan area. Type of municipality: (a) regenerating; (b) advanced ageing; (c) ageing; (d) maturing; (e) youthful; (f) model of stages across a municipality's housing life cycle. (Source: Newton et al., 2011)

A metropolitan-wide assessment of residential redevelopment potential undertaken for Melbourne in 2016 using ENVISION software (Glackin, 2013) revealed that over one-third of the city's 32 municipalities had more than half their housing stock with high redevelopment potential (Fig. 1.8). This represents approximately 660,000 individual residential properties with an RPI index $>0.7$ across the city $(23 \%>0.8$ and $9 \%>0.9)$. Research indicates that when properties with an RPI $>0.7$ come onto the market, they are typically redeveloped within six years, which is significantly more quickly than those with a lower RPI (Newton, 2010).

Fragmented lot-by-lot redevelopment encouraged under current metropolitan residential planning schemes results in knock-down-rebuild and small-lot low-density subdivision-with adverse impacts on the sustainable development of cities. Figure 1.9 illustrates the virus-like spread of piecemeal residential redevelopment in a typical middle-ring Melbourne suburb over a decade. This is progressively inhibiting the potential for higher-yield regenerative urban redevelopment at precinct scale while at the same time destroying urban green space. 


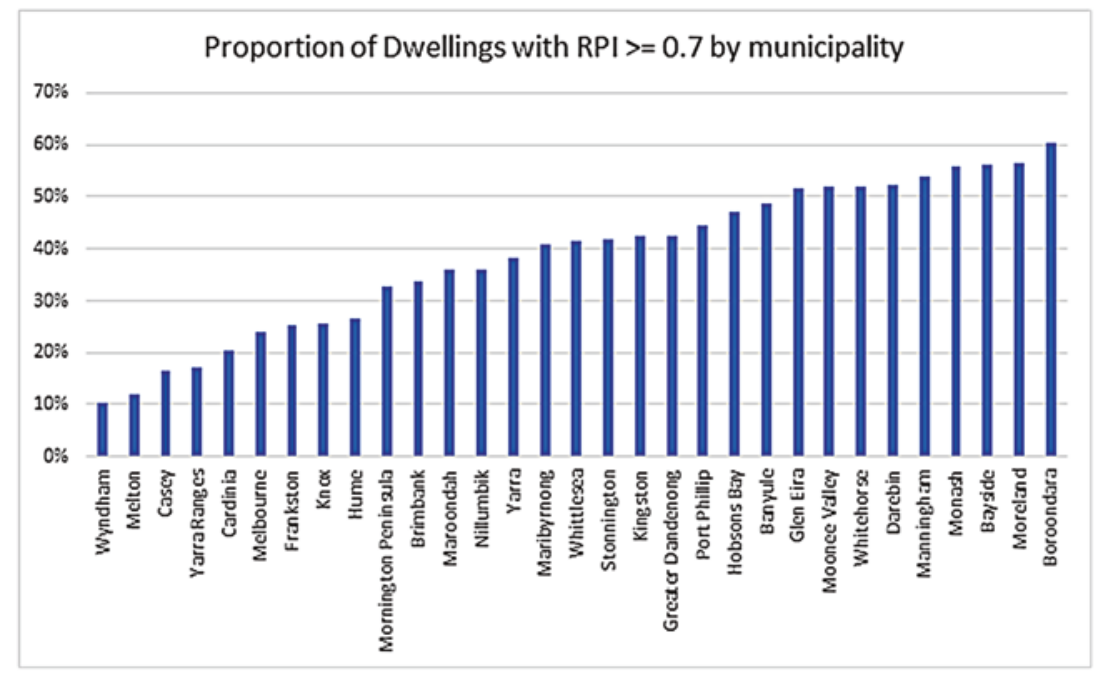

Fig. 1.8 Residential redevelopment potential of properties across Melbourne municipalities, 2016. (Source: Derived by authors from Victorian Valuer General 2016 rates data set)

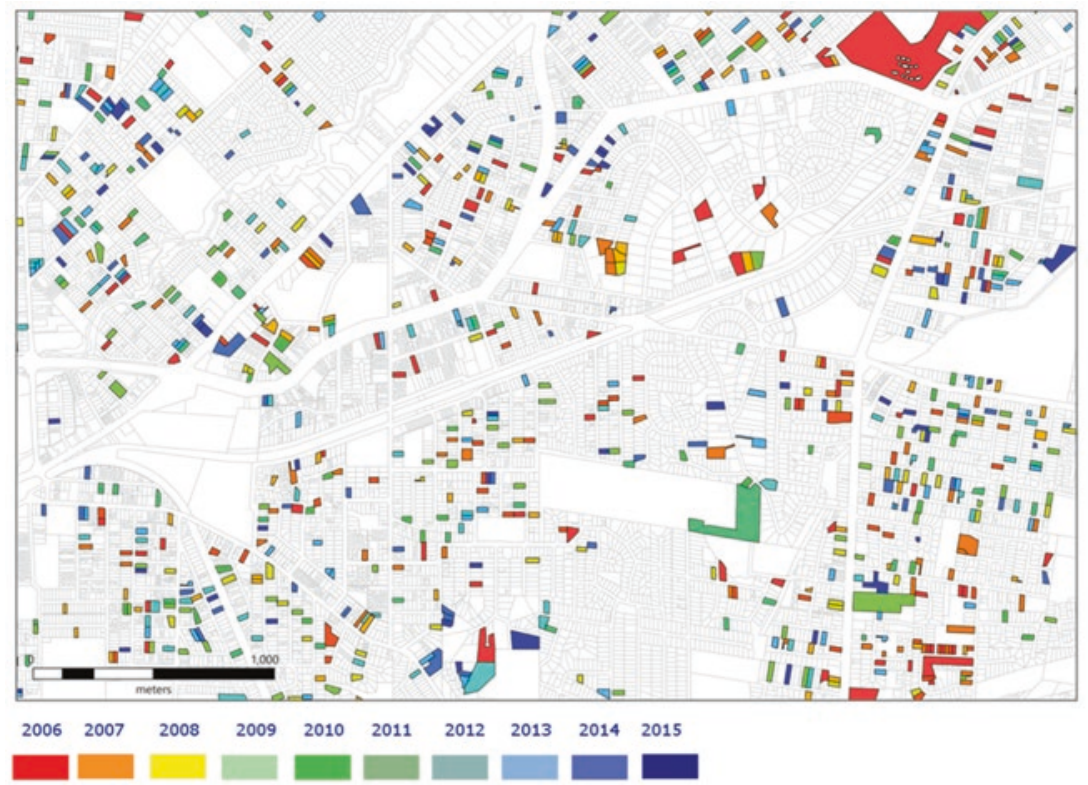

Fig. 1.9 The virus-like process of fragmented infill redevelopment in the City of Maroondah, Melbourne, 2006-2016. (Source: Newton et al., 2020) 
Transition 4 Implement a planning and land-assembly scheme that supports planning of greyfields regenerative residential redevelopment that is more agile and forward-looking and enables precinct-scale medium-density projects yielding more housing, more sustainably, by incentivising lot consolidation among neighbouring property owners or by requiring minimum lot sizes for infill redevelopment (voluntary lot consolidation is a focus of Chap. 7).

\subsection{Transition 5: Changing Household Structures and Composition}

Several significant demographic shifts are underway in the twenty-first century that are beginning to reshape urban housing markets. Principal among these is the maturation of the large 'baby boomer' generation (those born between 1946 and 1964). They are beginning to make an impact as many downsize from their under-occupied (and owneroccupied) housing (Newton et al., 2011; James et al., 2020) and look for appropriate dwellings and locations to occupy in retirement. The most sought-after neighbourhoods are typically those located close to where many currently live: in the established suburbs. Smaller medium-density units best suited to empty nesters are in short supply in these areas, however, and new stock for this type of housing is priced closer to that of older greyfield detached housing, which leaves smaller profit to add to retirement savings, and less incentive to move. This is unless neighbours in this age bracket combine their properties to sell as a consolidated precinct for redevelopment. In this case, evidence suggests that they will reap a higher dividend than if the properties are sold separately.

A real estate 'package' for medium-density dwellings in a well-located middle-ring suburb is also well suited to meeting the needs of several other household types. Single-person households, couples without children, and single parents are projected to increase at about twice the rate of the nuclear family (couples with children); thus, housing production in Australia and other countries with low-density suburban cities needs to dramatically increase housing that fits these needs (McGee, 2016). 
Appropriate configurations of twenty-first-century housing need to be incorporated in GPR to enable people to live near the services and functions they are used to.

Transition 5 Support a property-development industry capable of matching demand from an increasing diversity of household types and life-cycle stages with supply of more dwelling types that enable people to live longer in their desired locality (a focus of Chaps. 3, 5, 6, and 7).

\subsection{Transition 6: Overcoming Multiple Problems of Sprawl and Regenerating Car-Dependent Suburbs}

The pattern and rate of development characterising contemporary fastgrowing cities is increasing the urgency of identifying transition pathways capable of reshaping cities to be more productive, sustainable, liveable, inclusive, and resilient (the set of performance goals established by the Council of Australian Governments (COAG, 2011) for Australian cities and made global through the UN's New Urban Agenda). A principal planning intervention that is aligned with all these transition goals is halting urban sprawl by accommodating growth in a more sustainable and equitable manner through re-urbanising the ageing, established, lowdensity, car-dependent greyfield suburbs.

An extensive literature on this topic links sprawl with:

- Urban footprints that are increasing at a faster rate than population in many cities, and are associated with loss of productive agricultural and ecologically valuable land; an extension of settlement into areas of high wildfire risk; and expanding the impacts of urban heat islands.

- Ecological footprints that are world-leading due to large carbon footprints and high resource consumption and are typically three times the world average in low-density cities in developed countries (Newton, 2012) (Fig. 1.10). The challenge for these cities is to radically shrink 
1 The Global Greyfields Transition: Why Urban Redevelopment...

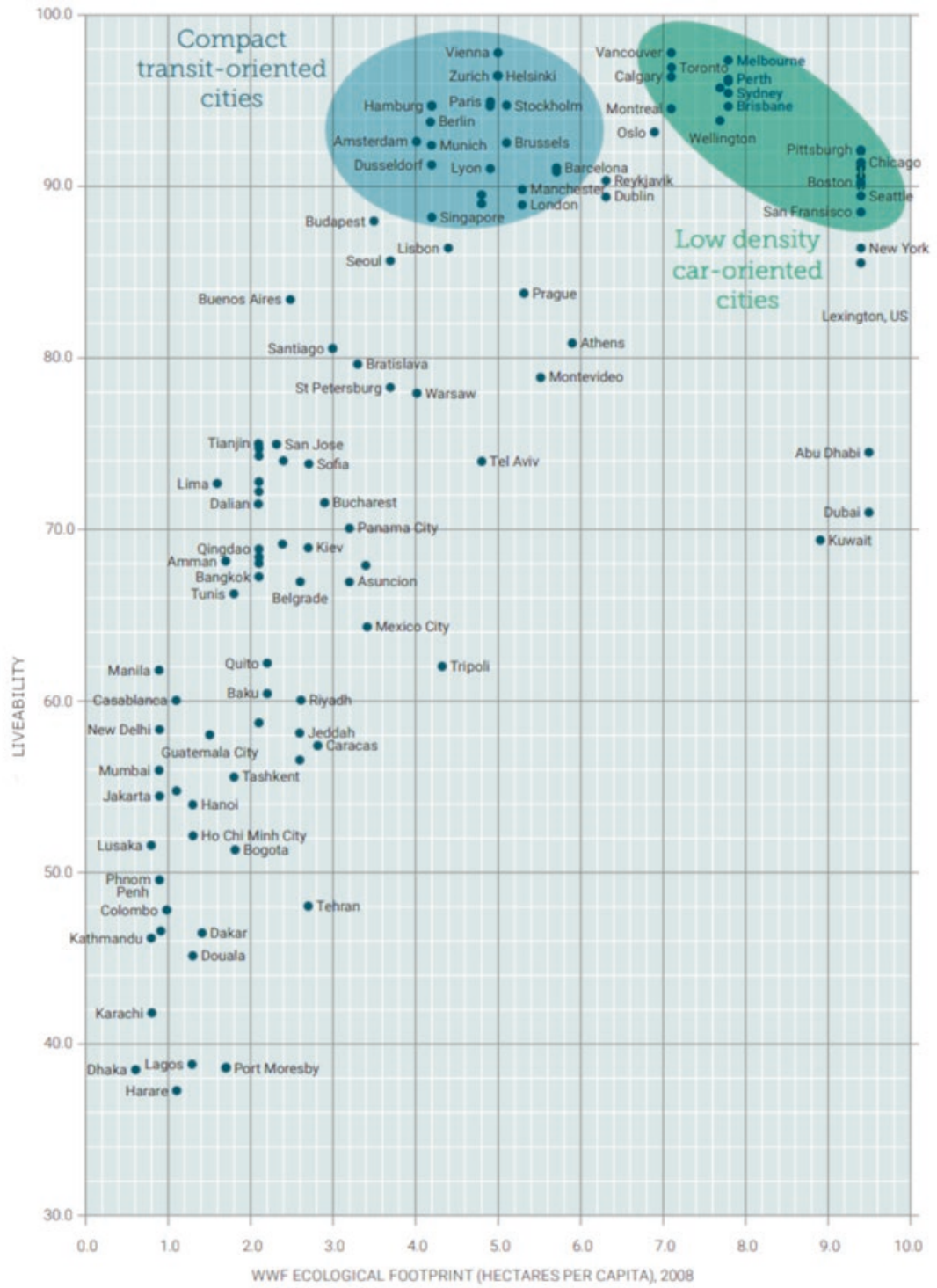

Fig. 1.10 The liveability-sustainability nexus of cities. (Source: Drawn from data published in Newton, 2012) 
their footprints while retaining their high levels of liveability-something that many European cities have demonstrated is feasible, as reflected in smaller, less consumptive housing and low-carbon walking and transit fabrics (Newman et al., 2017).

- Loss of economic and social productivity among car-dependent suburban populations associated with time spent commuting in daily activity budgets and their associated automobile costs (Newman \& Kenworthy, 2015).

- Loss of health, especially as a result of obesity-related chronic diseases linked to residence in car-dependent suburbs and neighbourhoods that discourage physical activity, especially walking (The Lancet, 2016).

- Increasing suburbanisation of social disadvantage, where households on lower incomes, dealing with social problems and requiring a range of services not available in greenfield areas, are excluded from unaffordable inner and mid-city housing and rental markets (Hulse \& Pinnegar, 2015).

- Reduced physical access to centralised metropolitan job markets, higher education, and specialist health services (McDougall \& Spiller, 2016).

- Higher cost of providing infrastructure for new housing in outer suburbs compared to infill in greyfields. The costs of sprawl have been estimated for decades; in Australia, Trubka et al. (2010) have suggested that 30 years of urban development focused on inner and middle suburbs would save $\$ 213$ billion compared to further developing the urban fringe.

COVID-19 has raised a number of questions associated with envisioning the future city and suburb, especially in relation to telework, commuting, and a changing relationship between home and workplace. The pandemic has reinforced the importance of local accessibility and local amenities (shops, services, recreation, parks): i.e. the 20-minute neighbourhood. During 2020, it became clear that many aspects of contemporary cities and built environments are no longer fit for purpose and are not being positioned for the century ahead. Key urban transitions will need to involve decarbonisation of the built environment, nature-based urbanism linked to integrated, decentralised urban water systems in 

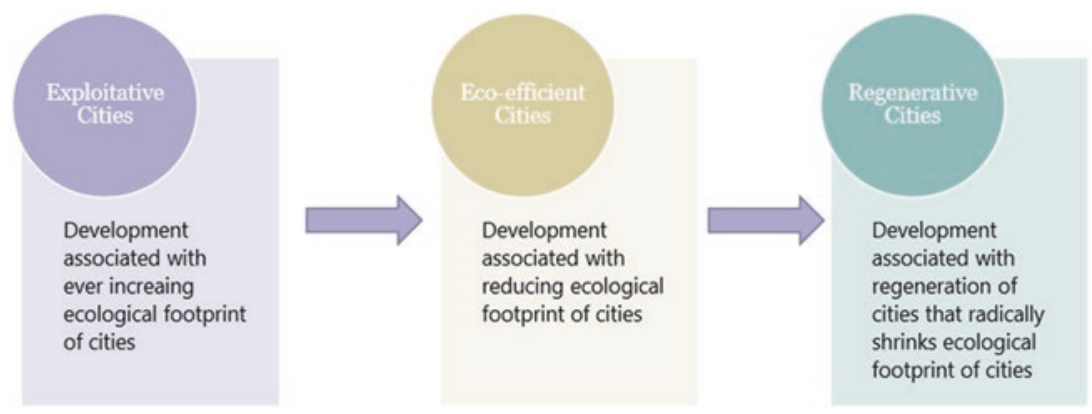

Fig. 1.11 The transition to regenerative cities. (Source: Newman et al., 2017, p. 13)

warming cities with declining rainfall, a circular urban economy, smart distributed urban infrastructures, and new forms of urban governance. All these are drivers of the new precinct-based housing and mobility models that feature in the following chapters, especially in regard to how they contribute to a new era and landscape of regenerative urbanism (Fig. 1.11).

This transition pathway seeks to close the door on a model of city development that has been demonstrably exploitative by putting economic objectives ahead of social and environmental concerns. An 'ecoefficiency' framework has emerged over recent decades, which represents an attempt to assess both the positive and negative environmental impacts associated with development projects, with a view to incorporating the results in urban decision-making processes. It recognises that environmental as well as economic calculations need to be involved in builtenvironment decision-making. The objective is to reduce environmental impact subject to cost, but the primacy of economic performance is typically evident - to some extent due to challenges associated with measuring the positive economic values of urban ecosystem services as well as the negative externalities linked to business-as-usual types of urban development, and incorporating both in the development project's spreadsheet. An inhibiting factor here is that contemporary governments are typically ill-disposed toward regulation requiring the additional measurement inherent in triple bottom-line project assessment; instead, they tend to 
favour industry-supported voluntary (often check-box) schemes for performance assessment.

'Regenerative urbanism' has emerged as a new objective for urban development that presents the opportunity and challenge to go beyond minimal reductions in environmental impact to a new vision of how cities can be designed and operate in an 'eco-positive' manner, while maintaining or enhancing liveability (Birkeland, 2008; Thomson \& Newman, 2016, 2018, 2020); in other words, removing negative environmental impacts from development and providing ecological gain. This requires regenerative development that is based on 'giving back as well as taking' (Girardet, 2015, p. 11) and needs to operate across all urban sectors and all urban scales: buildings, precincts, and cities. Regenerative urbanism relies heavily on the use of the urban metabolism model framework for representing (and measuring) the flow of resources into and waste outputs from built environments. It highlights the transformational changes that need to occur in urban systems (after Thomson \& Newman, 2016, 2018, 2020; Thomson et al., 2016):

- Going beyond reducing consumption of virgin non-renewable resources by transitioning to regenerative resources: creating more renewable energy than needed, using energy generated by rooftop solar while reducing demand by building highly energy-efficient buildings - in combination, a pathway to zero-carbon buildings; significantly reducing the need to import potable water due to the emergence of integrated water systems; and increasing the dematerialisation of industrial and construction products by the use of eco-efficient circular-economy materials, technologies, and processes.

- Going beyond reducing emissions to the air and to solid and liquid waste streams to repairing the ecosystems damaged by industrial and domestic emissions. This would mean both an increased focus on the decarbonisation of energy and deep mitigation of greenhouse gases via sequestering carbon in regional forestry projects and other carbon sinks such as wetlands and soils. It would also mean capturing and treating stormwater and wastewater for non-potable urban water uses and creating zero-waste pathways for industrial, construction, and 
domestic waste streams linked to a transition to a circular economy based on industrial-ecology principles.

- Creating smart urban systems and processes to enable cities to have an ecosystem of technologies that enable sharing of resource use and better integration of their infrastructure systems. Such systems will enable more effective and efficient economic, social, and environmental planning and management of cities, as well as better integration of the different levels of government with industry and community stakeholders (smart strategies as well as smart technologies).

- Meshing grey infrastructure with green infrastructure linked to biophilic design on, in, and around buildings to improve the public and private urban environmental quality as well as responding to the environmental stressors from reduced private green space associated with the intensified urban retrofitting and densification of cites. Introduction of water-sensitive urban design and nature-based services into GPR processes improves surface permeability and reduces stormwater runoff as well as reducing urban heat and improving biodiversity. This is especially important in the face of global warming.

- Creating micro-utilities (based on next-generation distributed energy, water, waste, and mobility systems) in designated greenlined urban districts that can increasingly be managed as an integrated enterprise capable of aggregating all the systems and flows (see Fraker, 2013).

- Enhancing liveability and well-being. Due to the extra density and accessibility in GPR, community services and broader city-wide services will be attracted to place-activated and transit-activated precincts to help deliver full-service communities. It can also enable the entire metro region to embrace the more-regenerative processes inherent in GPR by showing how they can move from greyfields into the outer greenfield suburbs. This would enable equity and access to be regained, providing communities in all urban fabrics a more equal share in city liveability.

- Elevating the resilience of cities. Implementing smart, sustainable planning and design technologies and management systems in the retrofitting and regeneration of cities will increase their resilience to storms, floods, heat, fires, and other disruptions through greater adaptive capacity now available as twenty-first-century technologies become 
affordable. There would also be an increased ability to cope with shocks linked to volatile global financial markets and health pandemics.

Transition 6 Devise regenerative metropolitan development strategies and new planning and development models such as GPR to enable transformative change at building, precinct, and city levels that is capable of halting further urban sprawl and helping create sustainable, resilient, inclusive, affordable city development (a focus of Chaps. 2, 3, 4, 5, and 7).

\subsection{Transition 7: Aligning Metropolitan Planning Strategies with Urban Redevelopment Needs}

Urban redevelopment currently occurs in two contrasting urban arenas: brownfields and greyfields. They can be distinguished by the planning, zoning, and development processes involved and the scale and dwelling yield of the on-ground projects. To date, greyfield residential infill redevelopment has been occurring in three urban settings prescribed in metropolitan zoning schemes: activity centres, major transport corridors, and fragmented infill in zoned residential areas. Figure 1.12 illustrates a full range of existing and prospective greyfield redevelopment models.

Activity centres, ranging in scale from the CBD to the more numerous 'principal' and 'major' activity centres characteristic of poly-centred development in large cities (i.e., those involving retail and commercial activity centres) to a myriad of neighbourhood activity centres that constitute the basis for '20-minute neighbourhoods'. They have been a central plank in Australia's metropolitan planning schemes for decades, and in more recent times have featured in attempts to further intensify growth via transit-oriented development (TOD) of larger activity centres linked with railway stations. The larger activity centres have been zoned as growth precincts to attract high-density apartment and commercial development.

Major transport corridors, a more recent model for greyfield redevelopment, involves identifying linear transport corridors along main roads as 


\section{Key Elements of Planning Strategies for Greyfield planning \\ Graphical \\ Representation}

Metropolitan and Major Activity Centres [also includes major urban renewal precincts]

Source: DELWP

Mooney Valley Activity Centre $[\rightarrow \rightarrow]$

Neighbourhood Activity Centres, greyfield retail strip or box centres Source: DELWP

Footscray Neighbourhood Activity Centre $[\rightarrow \rightarrow]$

Transit Orientated Development: Railway Station Anchored Source: Dovey and Woodcock (2014)

Subiaco

Station TOD $[\rightarrow \rightarrow]$

Transport Corridor Development: main road or tram route focused

Source: Adams (2009)

Maribyrnong Road corridor [ $\rightarrow$ now $\downarrow$ future]
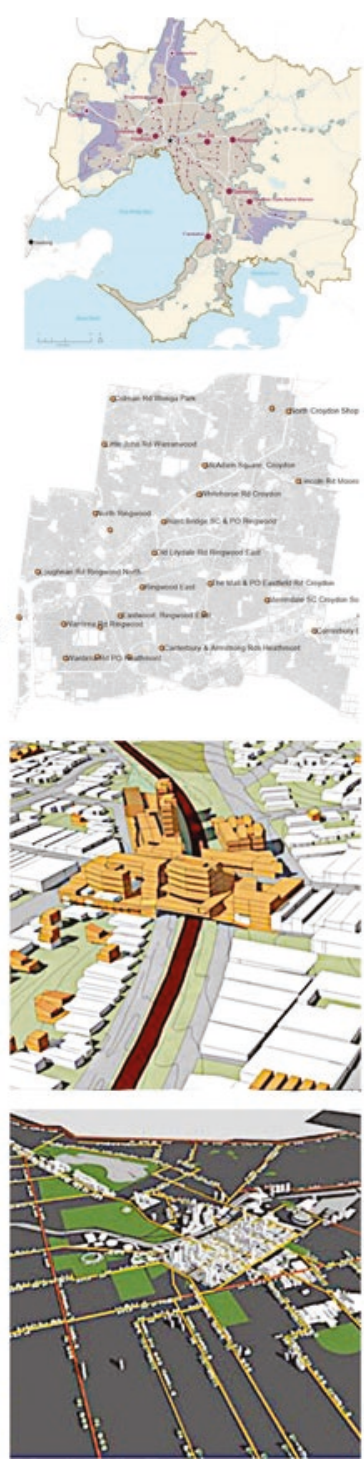

\section{Realisation}
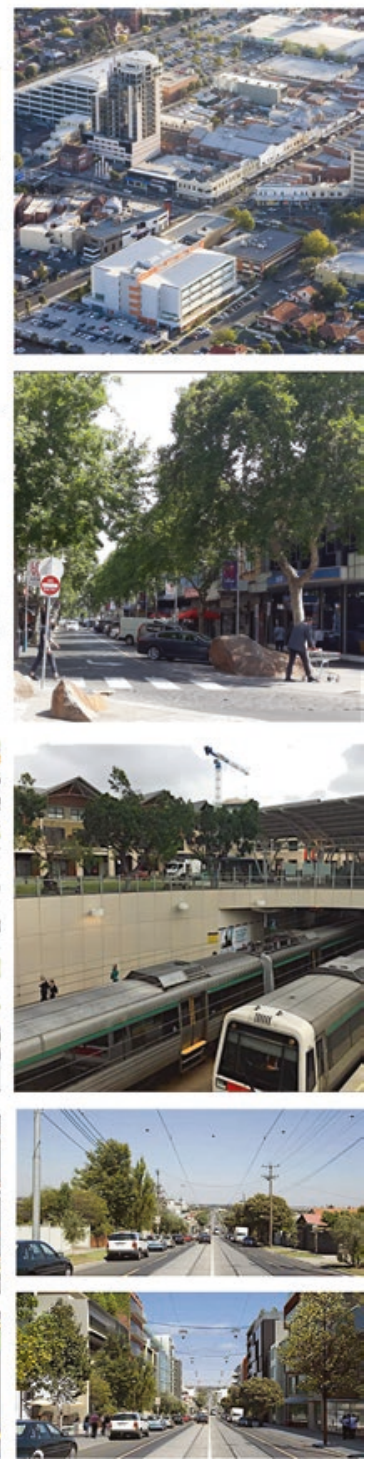

Fig. 1.12 Greyfield planning strategies for accommodating urban growth 


\section{Key Elements of Planning Strategies for Greyfield planning \\ Graphical \\ Representation}

Transit Activated Corridors: a connector of precincts

Source: Glazebrook and Newman (2018)

Trackless Tram $[\rightarrow \rightarrow]$

Greenspace Oriented Development

Source: Bolleter and Ramalho (2020)

Heller St Park and Residences $[\rightarrow \rightarrow]$ Source: https:// architectureau.com/ articles/the-common/

Fragmented Infill: Small Lot Subdivisions Maroondah, 2005-2016

Typical poor-outcome infill development $[\rightarrow \rightarrow]$

Greyfield Precinct Regeneration : Place Activated Precinct

Design precinct outcome $[\rightarrow]$

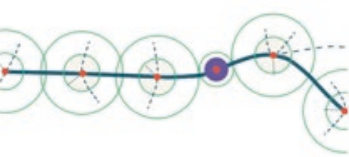

The and Station Autonomous Feeder

........ Autonomous Distributo Station Walking t.t.
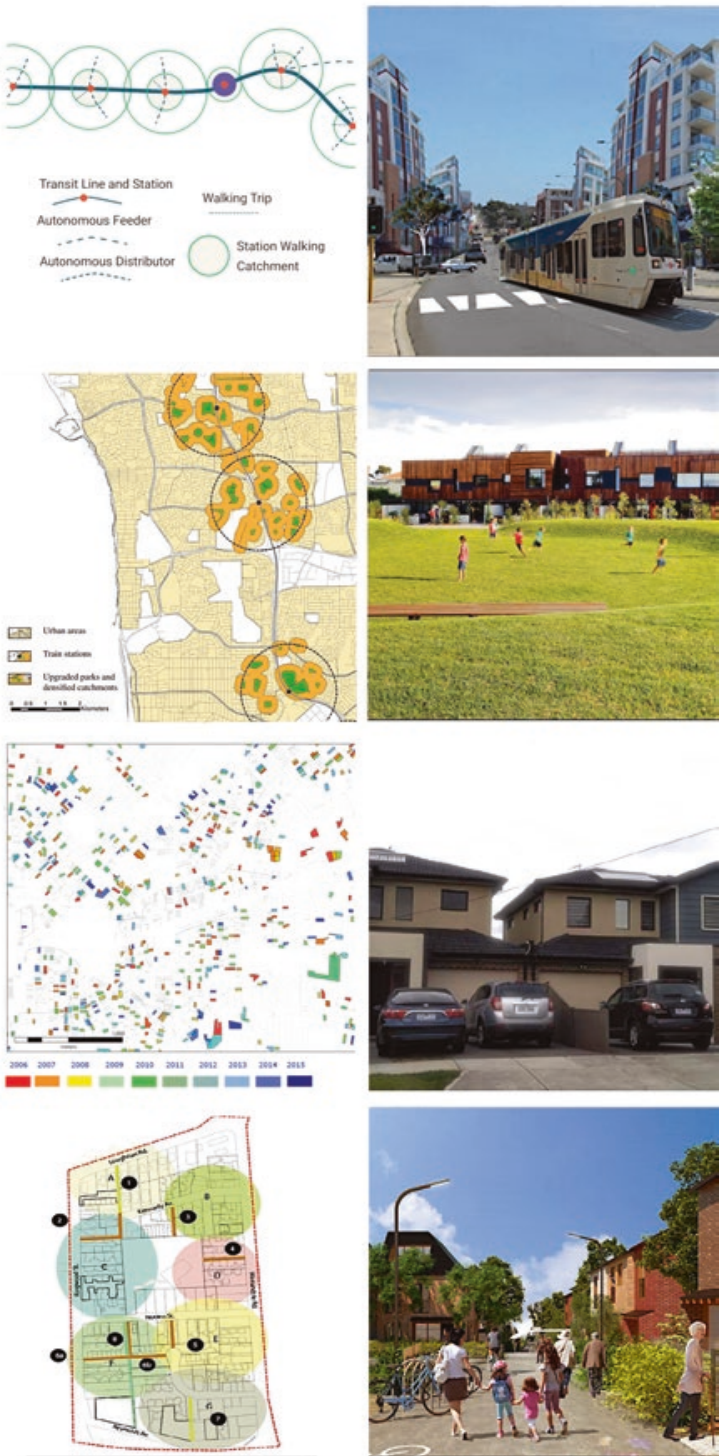

Fig. 1.12 (continued) 
an additional focus for medium-rise, high-density development. The requirements for this to work in Melbourne were set out by Adams (2009); they include prescriptive zoning controls over key aspects of corridor development, including upfront 'as of right' development to levels of between four and eight storeys. Much of this model has been built along the inner tram corridors of Melbourne and is now moving into middle suburbs. The need to build for reduced car parking in such transitactivated GPR has now become a much firmer planning principle that should be continued into the GPR planning schemes in future (McClosky, 2009).

The Melbourne corridor model of urban development from Adams (2009) has now been extended into greyfields where no tram systems currently exist (Newman et al., 2019). This transit-activated corridor (TAC) model involves threading new low-carbon mobility infrastructures (light rail, trackless trams, walking and cycling paths) through greyfield precincts in car-dependent suburbs based on new planning partnerships. A recent study by Hendrigan (2020) showed that the next 30 years of urban development in Perth could be accommodated by infill of no more than five storeys around rail stations and along new light-rail lines, mostly in middle suburbs; this topic is developed further in the transit-activated GPR model outlined in Chap. 4.

Green space-oriented development has been advanced as a new model for more-sustainable greyfield redevelopment that is focused on the potential for selectively and creatively redesigning and re-zoning residential areas abutting parks. This would involve re-zoning, buying out, and assembling neighbouring properties and rebuilding at higher densities on the flanks of public parks, especially those accessible to shops and rail stations via walking or cycling (Bolleter \& Ramalho, 2020; Weller, 2019). This is a variant of place-activated GPR, but depends on accessing parkland space, which is not as commonly available as the opportunities across most greyfield suburbs.

In Australia, each state government's planning provisions have residential zones that provide for a range of forms and intensities of development outcomes. Though the names and legislative underpinnings vary, they can largely be referred to as 'no-go' (highly restricted redevelopment), 'slow-go' (limited redevelopment), and 'go-go' (large-scale, high-density 
Table 1.1 Principal residential zones in Australia's largest capital cities

\begin{tabular}{llll}
\hline \multirow{2}{*}{ City } & Residential zone type & & \\
\cline { 2 - 4 } Melbourne & 'No-go' & 'Slow-go' & 'Go-go' \\
& $\begin{array}{c}\text { residential zone (and } \\
\text { low-density residential } \\
\text { zone) }\end{array}$ & $\begin{array}{c}\text { General } \\
\text { residential } \\
\text { zone }\end{array}$ & $\begin{array}{c}\text { Residential growth } \\
\text { zone and mixed- } \\
\text { use zone }\end{array}$ \\
Sydney & R2 low density residential & $\begin{array}{c}\text { R1 general } \\
\text { residential }\end{array}$ & $\begin{array}{c}\text { R3 medium density } \\
\text { residential }\end{array}$ \\
& & & R4 high density \\
& & & residential \\
& & & B4 mixed use \\
Brisbane & Character residential and & Low-medium & High density \\
& low density residential & residential & residential \\
& & density & \\
& & Medium density & \\
Perth & $\leq$ R15 & residential & \\
\hline
\end{tabular}

redevelopment); these are illustrated for the largest capital cities in Table 1.1. Application of specific zones sets the built-form and regeneration outcomes, and by altering the zone it is possible to alter expected outcomes. Evidence suggests that a particular zoning does not mean that the expected development always follows, as the market for housing depends also on what amenity is also associated with the housing being built not just its density zoning (Limb \& Murray, 2021). However, certain zonings such as the Neighbourhood Residential Zone (illustrated in Fig. 1.13) that covers extensive tracts of Melbourne's suburbs effectively 'locks out' the prospect for more regenerative medium density residential infill projects of the type outlined in this book.

A majority of residential areas in Australian cities are zoned as either 'no-go' or 'slow go' in relation to higher-density redevelopment. Consequently, fragmented infill represents the majority of housing redevelopment currently occurring in greyfields. It typically involves the construction of between one and four new dwellings on an established 'knock-down-rebuild' site, where the value of the land accounts for $70-80 \%$ or more of the value of the property asset prior to its redevelopment. It represents suboptimal redevelopment in many respects in that it generates a relatively low yield in terms of net new housing but is 


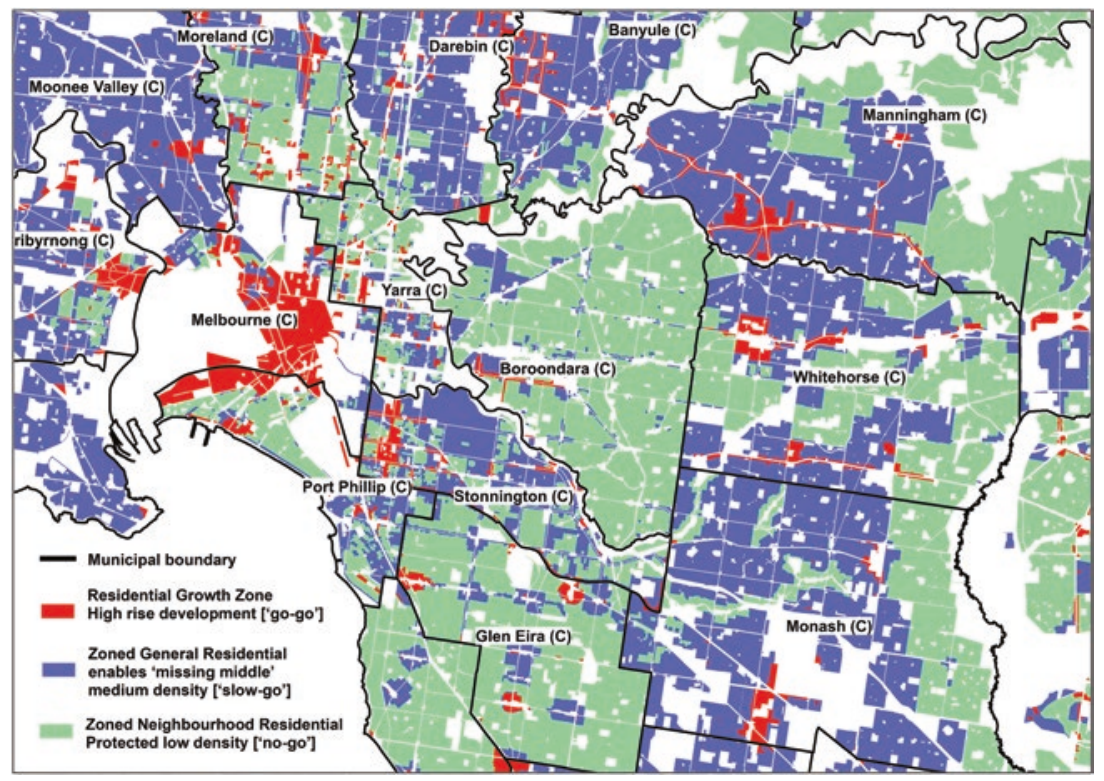

Fig. 1.13 The geography of residential zoning in Melbourne 2021. (Source: Planning layer from data.vic.gov.au)

accommodated within existing planning and building regulations, and as such has become a well-established model for small-scale property developers. However, it represents a slow burn of the local, public urban resource base:

- Loss of green character and amenity - there is significant loss of (private) open/green space with the removal of gardens, canopy trees, and lawn that are typically part of older detached housing.

- More people - additional population adds to the demands on municipal services without infrastructure improvements that can be incorporated in larger-scale precinct developments.

- More traffic-more households currently means more cars and added road congestion, particularly without additional public transport services or car sharing.

- No extra services - the scale of redevelopment usually means that the project does not attract a developer contribution that can assist government in redressing the associated negative externalities. 
Transition 7 Redevelopment policies and strategies for greyfields do exist but the majority of activity is suboptimal urban redevelopment which is built into the planning system in most redeveloping car-dependent cities and needs to be reviewed and revised at all planning levels and functions in order to transition to more regenerative urban redevelopment (a focus of Chaps. 3, 4, 5, and 7).

\subsection{Transition 8: Overcoming Failure of Current Urban Infill Strategies to Achieve Sustainable Redevelopment and Targeted Housing Yields}

Managing sprawl in Australia's largest cities will require at least $70 \%$ of net new housing to be constructed as infill within the strategic planning framework outlined above. Early reviews of urban consolidation policies reported no observable impact on this target (Goodman et al., 2010, p. 73).

A comprehensive review of housing infill outcomes in Melbourne over the past decade (Newton \& Glackin, 2014; Newton et al., 2020) has also established multiple shortcomings in specific elements of metropolitan strategies. In Melbourne, where the most comprehensive infill studies have been undertaken, approximately $50 \%$ of new housing is infill (brownfield-to-greyfield ratios vary depending on developer preferences for apartment construction, but are currently about 2:1, given that most high-rise apartment development is in the form of large brownfield projects). The public-transport access level of metropolitan road networks is not a magnet for attracting higher levels of infill (as most main roads just have poor-quality bus services, leaving households attached to car use and causing developers to continue to offer dual car parks, even in some apartments on tram routes). Nor are designated activity centres attracting significant new housing, with the exception of the CBD pre-COVID-19; Limb and Grodach (2020) offers similar evidence for Brisbane. Figures 1.9 and 1.14 illustrate that most residential infill in middle-ring greyfield suburbs is piecemeal, small-lot subdivision. 


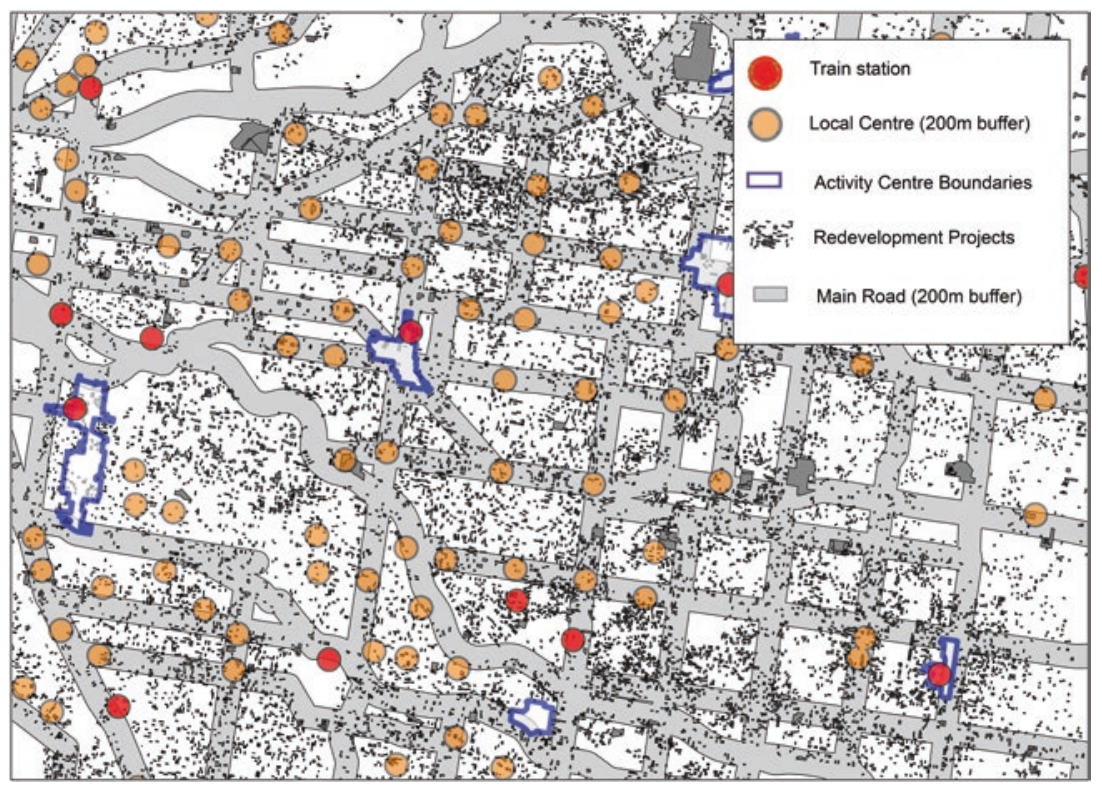

Fig. 1.14 Location of infill housing projects in the context of strategic planning schemes: City of Maroondah 2015; demonstrating that the majority of greyfield infill is not strategically aligned. (Source: Derived from Victorian Government spatial data)

Transition 8 Continue to develop and implement GPR policies and strategies as a response to the fact that most metropolitan planning is failing to deliver the kind of housing and transport outcomes that are set in their strategic plans (a focus of Chaps. 2, 6, and 7).

\subsection{Transition 9: A New 'Missing Middle' Model for Housing and Urban Redevelopment: Greyfield Precinct Regeneration}

A focus on the location and scale of greyfield infill redevelopment projects is revealing. There continues to be a lack of residential construction projects in greyfields that yield between 5 and 20 new medium-density 
Table 1.2 Dwelling yields of residential infill construction projects in Melbourne 2005-2016

Project yield

(New dwellings as \% of total construction)

\begin{tabular}{lcllllllc}
\hline $\begin{array}{l}\text { Development } \\
\quad \text { arena }\end{array}$ & 1 & $2-4$ & $5-9$ & $10-19$ & $20-49$ & $50-99$ & $100+$ & Total \\
Brownfield & 2.0 & 0.5 & 0.6 & 1.6 & 8.4 & 8.9 & 27.0 & 49 \\
Greyfield & 13.0 & 27.7 & 5.3 & 3.9 & 0.5 & 0.4 & 0.1 & 51 \\
$\quad$ Total \% & 15.0 & 28.2 & 5.9 & 5.5 & 8.9 & 9.3 & 27.1 & 100 \\
Total (000) & 42.3 & 79.5 & 16.7 & 15.7 & 25.0 & 26.3 & 76.6 & 282.1 \\
\hline
\end{tabular}

Source: Newton et al., 2020

dwellings_a missing middle scale of residential redevelopment (Table 1.1). Larger-scale projects (specifically, high-rise apartment buildings) are concentrated in brownfields. The type of infill housing also varies by the area's socio-economic status: locations with above-average socio-economic status are where 1:1 replacement and high-rise apartments dominate; and those with average-to-below-average socio-economic status are where 1:2-4 and 1:5-9 projects dominate. This points to the challenge of lot consolidation and its role in GPR.

'Missing middle' is a planning and development concept that has only been partially conceptualised and applied in the urban literature. Previously, 'missing middle' was used exclusively as a term related to a set of medium-density housing types that sit between detached single-family homes and mid-rise town houses or apartment buildings (Parolek, 2019). Missing-middle policy approaches to urban infill development are happening in countries with low-density cities (such as the USA, Canada, New Zealand, and Australia) where attempts are being made to increase the supply of medium-density housing. However, as shown in Table 1.2, only small-scale, lower-density infill projects are being undertaken, as they more readily conform to existing low-density residential zoning codes and fabrics (discussed in more detail in Chap. 2).

In this work, we are advancing an extended definition of 'missing middle': medium-density dwelling typologies accommodated in precinct-scale redevelopment projects (Fig. 1.15) located primarily, but not exclusively, in a city's established, middle-ring greyfield suburbs (Fig. 1.16). If infill targets for new housing are to be met, then 'missing middle' needs to be seen to include medium-density housing with precinct-scale residential regeneration: GPR. 


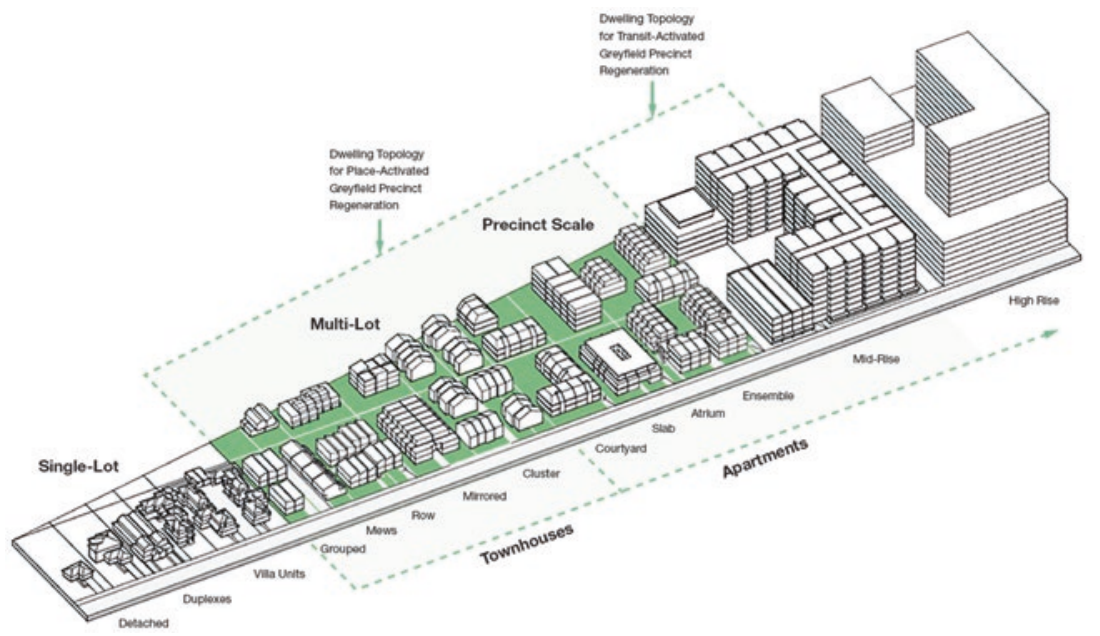

Fig. 1.15 The 'missing middle'-medium-density dwelling types in a greyfields mid-scale precinct redevelopment. (Source: Newton et al., 2020)

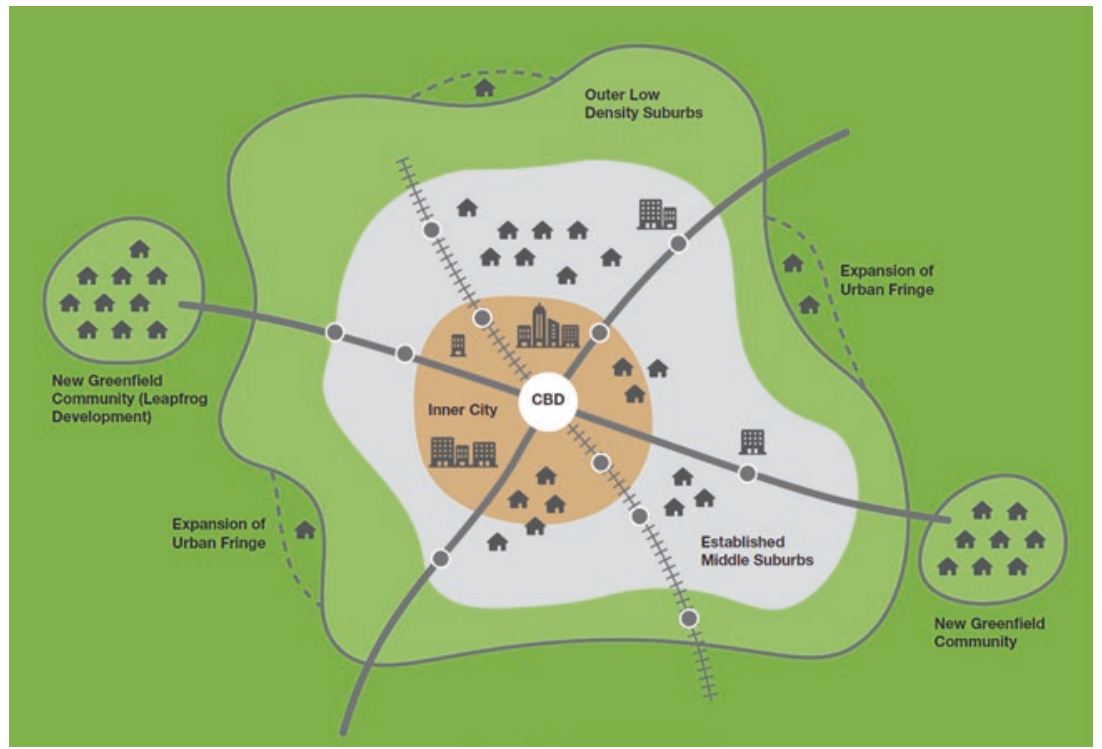

Fig. 1.16 The 'missing middle' greyfield suburbs of a city. (Source: Place Design Group, 2019, p. 43) 
Mid-rise (four- to eight-storey) apartments are more closely aligned to the scale of redevelopment envisaged for transit-activated corridors; while three- to four-storey medium-density dwelling typologies are a more appropriate scale for place-activated GPR in neighbourhoods away from main roads.

Transition 9 Move from fragmented 'missing middle' housing redevelopments to 'missing middle' medium-density precinct-scale regenerative redevelopment (a focus of Chaps. 2, 7, and 8).

\subsection{Transition 10: Establishing 'Precinct' as a Scale for Regenerative Redevelopment}

Precincts are the building blocks of cities, representing the scale at which most twentieth-century cities have been traditionally planned and developed. They also represent the scale at which established and ageing sections of cities can best be redesigned, retrofitted, and regenerated.

A precinct is a unified area of urban land with a clearly defined geographic boundary. In the context of this book, a precinct is synonymous with a neighbourhood or district. A typical precinct will contain private and public land with shared infrastructure. A defined boundary is critical to the notion of a sustainable precinct because many of the low-carbon precinct concepts involve distributed infrastructure that requires clear boundaries from a legal ownership and management perspective (this topic is the focus of Chap. 3). A well-defined boundary, with a clear governance structure, allows for the precinct to be managed and monitored at the local level, permitting it to function as an autonomous or semiautonomous piece of the city in which local managers drive ongoing and iterative improvements. Fraker (2013, p. 2) suggests that precincts represent opportunities to become integrators and aggregators of key builtenvironment infrastructures, both physical (energy, water, waste) and natural (such as green spaces), and depending on the size of the precinct, they have the potential to become their own micro-utility, as outlined in Transition 6 and Chap. 3. 
Precinct size can vary considerably; for example, the well-known sustainable precincts BedZED in London and Hammarby Sjöstad in Stockholm are 1.7 ha and 250 ha, respectively. The significance of size rests with the fact that distributed technologies tend to have physical thresholds and efficiencies, where the size of the land parcel available will influence the design approach and the technology solution.

Precinct Information Modelling systems now provide a flexible digital platform for precinct design and assessment that permits their boundaries, spatial contexts, and associated design attributes to be defined and redefined in real time to support scenario assessments in urban planning and development projects (a focus of Chaps. 7 and 8).

Precincts also need to be considered in relation to their wider geographic context. While a precinct approach is relevant for a neighbourhood or even a small town, far greater benefits play out at the city scale where multiple precincts interact. This is especially true when they are designed with the discipline of a cellular structure-that is, clustered around the local needs of a community such as for shops, services, and recreational space, or based on linkages between precincts via publictransport corridors, which greatly reduce private vehicle use and therefore carbon emissions, while improving connectivity between neighbourhoods (a focus of Chap. 4). Precincts also represent a scale at which regenerative redevelopment can contribute to mitigating neighbourhood as well as city-scale impacts of climate change, especially flooding and urban heat (a focus of Chap. 5).

Successfully producing long-term metropolitan policies, strategies, and plans capable of directing future urban development and redevelopment in an integrated fashion remains a challenge in terms of both horizontal planning (across provision of housing, transport, energy, water, waste, and social services) and vertical planning (across tiers of government and local communities). Identification of where and how to intervene and at what scale is especially challenging in greyfields. Opportunities for place-activated and transit-activated GPR involving local housing and infrastructure redesign and regeneration are ideally signalled by the new concept of district greenlining in metropolitan and municipal plans. District greenlining would be a first step in outlining the intention to regenerate a particular locality or series of localities; a process requiring vertically and horizontally integrated planning. This would enable the 


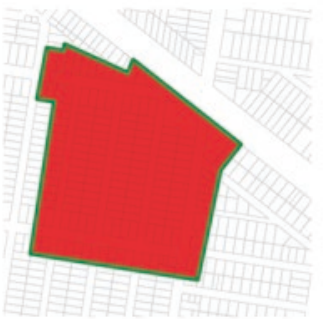

Brownfield Precinct

Consolidated strategic Green-lined site that includes public and private land upgrades and infrastructure retrofitting across the whole precinct

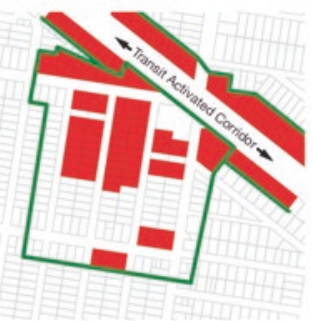

Greyfield Precinct: Consolidated Lots Green-lined district that involves public realm and urban infrastructure retrofitting plus land assembly of key parcels for density 'uplift' with distributed EWW eco-infrastucture and street upgrades

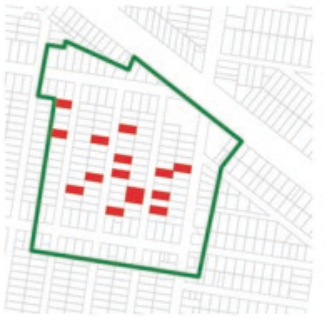

Greyfield Precinct: Dispersed Lots

Green-lined district that involves public realm and urban infrastructure retrofitting plus public housing estate renewal as catalyst for wider private sector housing regeneration

Fig. 1.17 District greenlining and nested precinct redevelopment

start of partnership development and community engagement (as outlined in Chap. 8) and allow planning to be scaled up in its ability to regenerate the middle suburbs. It would enable GPR projects to be attracted to and nest within districts that have been strategically identified in larger-scale and longer-term metropolitan and municipal planning strategies for urban densification and infrastructure retrofitting (Fig. 1.17). Ideally, district greenlining should be undertaken collaboratively between state and municipal planning authorities and major utilities as a necessary first step in identifying future strategies and timetables for major infrastructure retrofitting across the metropolitan area. In the absence of state-municipal level collaboration, future strategic planning by local governments needs to incorporate a district greenlining process to identify localities where change is required within their jurisdiction and where place-activated and transit-activated GPR projects are to be encouraged.

In summary, this book will show how and why precinct-scale redevelopment has the capacity to deliver more regenerative, resilient, and liveable neighbourhoods:

- Housing: greater yield; variety of dwelling sizes, types, and price points

- Mixed-use development: increased population provides opportunity for more commercial and retail services 
- Energy: net zero carbon precincts via energy-efficient dwelling shell, distributed renewable energy and storage, community renewableenergy schemes, and electric vehicles

- Water: integrated stormwater/rainwater/greywater systems; watersensitive dwelling and precinct design

- Waste: recycled construction and demolition waste; recycled domestic glass, paper and plastics; composting food waste

- Mobility and health: more walkable neighbourhoods; fewer cars, which are replaced by active transport, micro-mobility, and carsharing systems

- Green space: maintain and enhance rather than lose private green space; redesign and activate local streets by redistributing space from automobile to resident use; introduce biophilic design on buildings

- Community space: new pocket parks, rain gardens, local meeting spaces; literally hundreds of possible 'spontaneous interventions' primarily initiated by local residents (see Venice Biennale, 2012)

A growing number of design guides and assessment and rating tools are also available at precinct scale to assist design practitioners and municipal statutory planners lift the bar on urban infill projects, especially in relation to demonstrating the additionality associated with GPR projects (Chaps. 7 and 8).

Transition 10 Providing a regenerative precinct focus in all greyfield redevelopment starting with district greenlining.

\section{The Challenge of GPR: Charting the Transition}

GPR represents an aspirational mission-oriented project (Mazzucato, 2018) designed to strategically steer research and urban innovation activities in addressing significant metropolitan planning challenges of scale and scope-in this case remaking greyfield suburbs to be more 
regenerative and liveable in a suburban-to-urban transition (Newton et al., 2017). We introduce two new urban-development models capable of reactivating places and corridors at precinct scale (place-activated and transit-activated GPR), as well as district greenlining, which provides a broader strategic and spatial framework for specific regenerative projects.

The program of applied research has been guided by a framework that has evolved as a result of extensive co-design and co-production activities between researchers, government, industry, and community engagement (the Preface acknowledges them). The framework has enabled the development of new planning concepts, instruments, and processes that constitute the innovation levers necessary to initiate a GPR transition. Transition-management concepts and methods (Loorbach, 2007; Newton, 2018) guided the process, and the framework shown in Fig. 1.18

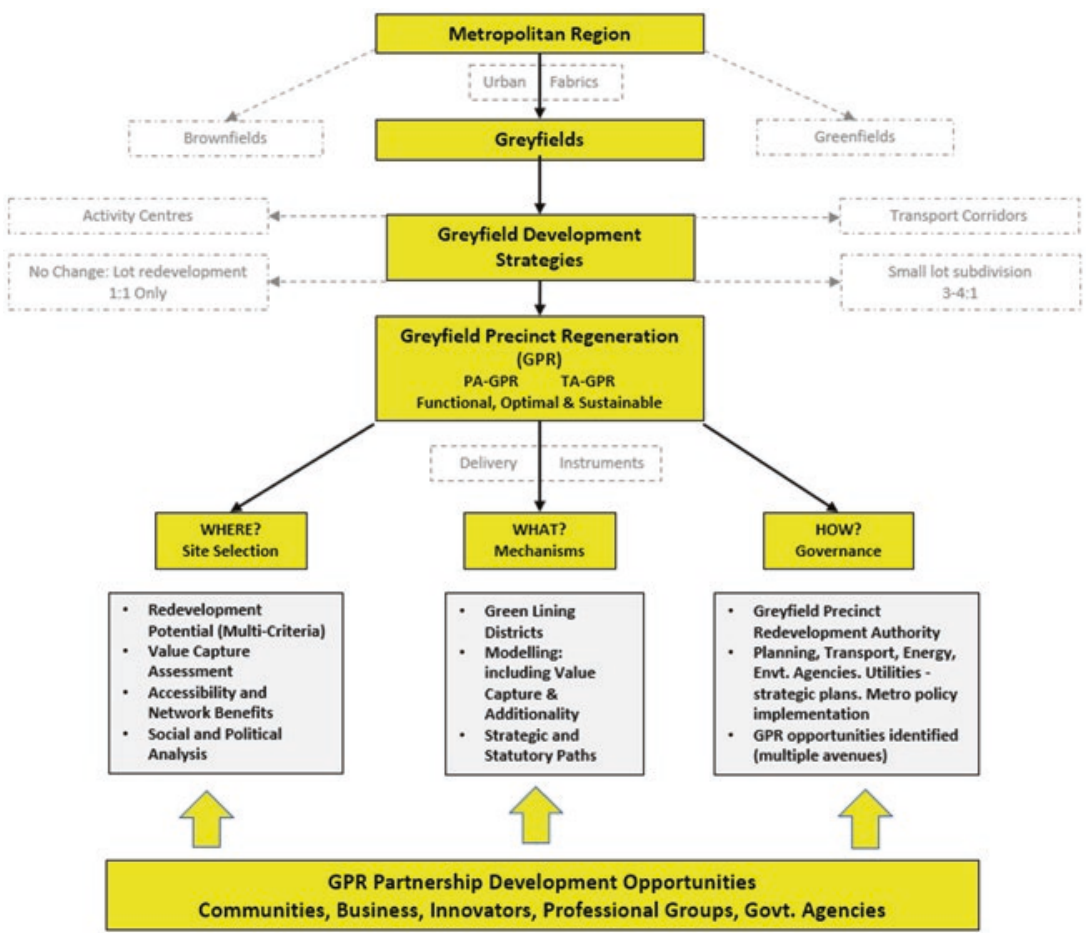

Fig. 1.18 Innovation arenas for establishing greyfield precincts 
illustrates key features of greyfields precinct regeneration research and implementation, including next steps.

The framework addresses three key questions:

1. Where should planners focus within a city and suburbs for candidate clusters of properties with high redevelopment potential suitable for place-activated and transit-activated GPR? New methods and tools were developed for housing-market assessment that can be aligned to future (municipal) strategies for urban regeneration and climate adaptation. These include a multi-criteria analysis process that highlights the capacity for enhancing active travel modes, green-space provision, and mixed-use development, as well as analysis that ensures an economically feasible yield of medium-density dwellings; and a demographic overlay identifying concentrations of neighbouring households potentially attracted to lot amalgamation by downsizing from under-occupied, ageing detached housing (a focus for Chaps. 2, 3, 4, 5, 6, and 7).

2. What should be redeveloped in a greyfield precinct? The process here is planning and design-led-a key integrative force in steering urban change by positively reshaping an existing urban morphology: buildings and streetscapes. Having identified a district with properties capable of consolidation into a place-activated or transit-activated greyfield precinct, the challenge becomes one of creating the optimal medium-density dwelling and landscape designs (and corridor layouts if transit-activated GPR) that can deliver demonstrably superior outcomes (additionality) compared to business-as-usual practice. As outlined earlier, our use of the term additionality refers to those attributes of neighbourhood regenerative redevelopment that need to accompany increased medium-density housing redevelopment; for example, zero-carbon energy, water-sensitive design and integrated water systems, improved mobility, social infrastructure, and enhanced green space-delivering multiple, measurable benefits to the local community.

Factors influencing the design process for GPR are outlined in all the chapters that follow.

3. How can GPR be delivered in the established low-density middle suburbs? The processes pioneered in Greening the Greyfields involve: 
- Achieving acceptance of the GPR model by state government strategic planners and ministers, thereby providing a signal to local government strategic planners that future municipal-planning schemes need to be able to accommodate this new category of urban redevelopment in the greyfields. This involves effectively making the process less risky by providing clear evidence of the advantages of GPR in the context of future urban development; and identifying preferred districts for intervention (district greenlining) in consultation with local governmentplaces where regenerative change needs to happen.

- Establishing a fit-for-purpose collaboration to achieve GPR, a partnership among relevant stakeholders to co-create and co-design a place-based vision and development pathway through to realisation. Key members of such a partnership are municipal and state government planning representatives, design and development professionals, urban technologists, and local community representatives. A GPR development partnership needs to be able to demonstrate the additionality that GPR can make to the locality as well as to property owners and developers (win-win-win). The performance-assessment tools and processes for deriving evidence of GPR benefits have been established and trialled (Newton \& Taylor, 2019; Newton et al., 2020). Local governments need to incorporate the specific GPR additionality requirements into their planning scheme when new precinct development overlays or broader re-zonings are established; otherwise such changes will increase the development yield and value of the land asset without creating value for the local community. A shift in focus to value creation and value capture will enable this. The new tools and processes are outlined in Chap. 7.

- Engaging with resident property owners in agreeing precincts to achieve lot consolidation, a transition from NIMBY to YIMBY. NIMBYism is a common, understandable community reaction to current urban infill policies that deliver no tangible benefits to local residents. The additionality benefits of GPR have been outlined in earlier sections, and they need to be demonstrated upfront for any GPR project - a basis for municipal planners as well as local residents to turn the 'no' into a 'yes' (Fig. 1.5). New community-engagement processes targeting lot consolidation have been established and demonstrated in collabora- 
tion with local government, and tailored to municipal ('town hall') and neighbourhood ('kitchen table') meetings.

- Developing a case for establishing a Greyfields Precinct Regeneration Authority with a mandate for developing and overseeing a pipeline of appropriately targeted viable and innovative precinct-scale projects. The Greening the Greyfields project identified this from the outset as a key strategy for thought leaders and urban practitioners who are addressing the greyfields redevelopment challenge (Newton et al., 2011), and most recently by the Property Council of Australia (PCA, 2020). It would complement the work of existing authorities established in Australia in delivering better urban development in both the greenfield growth areas and the brownfields redevelopment areas. Additionality would be a mandatory requirement for project approval by any Greyfield Precinct Regeneration Authority or local government. Consortia would be required to demonstrate additionality for the privilege (and profit) of a precinct regeneration project.

\section{Conclusion}

What is being demonstrated in this book is the emergence of a new urban-planning model, greyfield precinct regeneration, for regenerative urban redevelopment at the precinct scale that can address contemporary challenges facing fast-growing, low-density, car-dependent cities. As Newton (2019, p. 359) has argued: 'If cities are to achieve the international performance goals and objectives outlined by the United Nation's Sustainable Development Goals and the New Urban Agenda as well as those identified at a national level then it will be necessary for their constituent precincts to demonstrate performance outcomes that align with and add to, rather than subtract from, these objectives'. This applies to GPR whether it is place-activated or transit-activated. This book moves beyond the concept phase to show how new urban design, planning, and engagement processes can be enabled to make such urban innovation happen. 


\section{References}

Adams, R. (2009). Transforming Australian cities for a more financially viable and sustainable future. City of Melbourne and Department of Transport.

Australian Bureau of Statistics. (2015). Household and family projections, Australia, 2011 to 2036; cat no. 3236.0, Canberra.

Birkeland, J. (2008). Positive development. Earthscan, London.

Bolleter, J., \& Ramalho, C. E. (2020). Greenspace-oriented development: Reconciling urban density and nature in suburban cities. Springer.

Brotchie, J. F., Hall, P., \& Newton, P. W. (1987). The transition to an information society. In J. F. Brotchie, P. Hall, \& P. W. Newton (Eds.), The spatial impact of technological change (pp. 435-451). Croom Helm.

Council of Australian Governments (COAG). (2011). Creating places for people: An urban design protocol for Australian cities. https://urbandesign.org.au/content/uploads/2015/08/INFRA1219_MCU_R_SQUARE_URBAN_ PROTOCOLS_1111_WEB_FA2.pdf

Florida, R. (2017). The new urban crisis: Gentrification, housing bubbles, growing inequality, and what we can do about it. Simon and Schuster.

Fraker, H. (2013). The hidden potential of sustainable neighbourhoods. Island Press. Girardet, H. (2015). Creating Regenerative Cities. Routledge.

Glackin, S. (2013). Redeveloping the greyfields with ENVISION: Using participatory support systems to reduce urban sprawl in Australia. European Journal of Geography, 3(3), 6-22.

Glazebrook, G., \& Newman, P. (2018). The city of the future. Urban Planning, 3(2), 1-20.

Goodman, R., Buxton, M., Chhetri, P., Taylor, E., \& Wood, G. (2010). Planning and the characteristics of housing supply in Melbourne, AHURI Final Report No. 157. Melbourne: Australian Housing and Urban Research Institute.

Hendrigan, C. (2020). A future of polycentric cities: How urban life, land supply, smart technologies and sustainable transport are reshaping cities. Palgrave.

Hulse, K., \& Pinnegar, S. (2015). Housing markets and socio-spatial disadvantage: An Australian perspective. Australian Housing and Urban Research Institute Limited.

.id. (2018). Greater capital cities- dwelling type. https://profile.id.com.au/australia/dwellings? WebID $=260$

James, A., Rowley, S., \& Stone, W. (2020). Effective downsizing options for older Australians. AHURI Final Report 325. Australian Housing and Urban Research Institute Limited. 
Limb, M., \& Grodach, C. (2020). Compact city reset: Toward alternatives to market-driven density. Urban Policy and Research, 38(4), 287-290.

Limb, M., \& Murray, C. (2021). We zoned for density and got higher house prices: Supply and price effects of upzoning over 20 years. Working Paper. QUT.

Loader, C. (2015). Are Australian cities becoming denser? Charting Transport, 2017. Retrieved July 14, 2017, from https://chartingtransport. com/2013/11/05/are-australian-cities-becoming-denser/

Loorbach, D. (2007). Transition management. International Books.

Mazzucato, M. (2018). Mission-oriented research and innovation in the European Union: A problem-solving approach to fuel innovation-led growth. European Commission.

McClosky, D. (2009). Making public transport work in Victoria. Centre for Population and Urban Research, Monash University, Melbourne.

McDougall, A., \& Spiller, M. (2016). Attracting jobs to outer urban growth areas. https://www.sgsep.com.au/publications/insights/attracting-jobs-toouter-urban-growth-areas

McGee, C. (2016). Regenerating the suburbs: A model for compact, resilient cities. Proceedings, State of Australian Cities Conference, Gold Coast, QLD.

Newman, P., \& Kenworthy, J. (1989). Cities and automobile dependence. Gower.

Newman, P., \& Kenworthy, J. (2015). The end of automobile dependence: How cities are moving beyond car-based planning. Island Press.

Newman, P., Kosonen, L., \& Kenworthy, J. (2016). Theory of urban fabrics: Planning the walking, transit/public transport and automobile/motor car cities for reduced car dependency. Town Planning Review, 87(4), 429-458.

Newman, P., Beatley, T., \& Boyer, H. (2017). Resilient cities: Overcoming fossil fuel dependence. Island Press.

Newman, P., Hargroves, K., Davies-Slate, S., Conley, D., Verschuer, M., Mouritz, M., \& Yangka, D. (2019). The trackless tram: Is it the transit and city shaping catalyst we have been waiting for? Journal of Transportation Technologies, 9, 31-55.

Newton, P. (1995). Changing places? Households, firms and urban hierarchies in the Information Age. In J. F. Brotchie, M. Batty, E. Blakeley, P. Hall, \& P. Newton (Eds.), Cities in competition (pp. 161-190). Longman.

Newton, P. (Ed.). (2008). Transitions: Pathways towards sustainable urban development in Australia. Springer.

Newton, P. (2010). Beyond greenfields and greyfields: The challenge of regenerating Australia's greyfield suburbs. Built Environment, 36(1), 81-104. 
Newton, P. (2012). Liveable and sustainable? Socio-technical challenges for 21 st century cities. Journal of Urban Technology, 19(1), 81-102.

Newton, P. (2018). Transitioning urban greyfields. In T. Moore, F. de Hahn, R. Horne, \& B. Gleeson (Eds.), Urban sustainability transitions: Australian cases - International perspectives. Routledge.

Newton, P. (2019). The performance of urban precincts: Towards integrated assessment. In P. Newton, D. Prasad, A. Sproul, \& S. White (Eds.), Decarbonising the built environment: Charting the transition (pp. 357-384). Palgrave Macmillan.

Newton, P., \& Glackin, S. (2014). Understanding infill: Towards new policy and practice for urban regeneration in the established suburbs of Australia's cities. Urban Policy and Research, 32(2), 121-143.

Newton, P., \& Taylor, M. (2019). Precinct design assessment: A guide to smart sustainable low carbon urban development. CRC for Low Carbon Living.

Newton, P., \& Thomson, G. (2017). Urban regeneration in Australian cities. In P. Roberts, H. Sykes, \& R. Granger (Eds.), Urban regeneration: A handbook (Rev. ed., pp. 228-313). SAGE.

Newton, P., Murray, S., Wakefield, R., Murphy, C., Khor, L.-A., \& Morgan, T. (2011). Towards a new development model for housing regeneration in greyfield residential precincts. Final Report no. 171. Australian Housing and Urban Research Institute.

Newton, P., Newman, P., Glackin, S., \& Trubka, R. (2012). Greening the greyfields: Unlocking the redevelopment potential of the middle suburbs in Australian cities. World Academy of Science, Engineering and Technology, 71, 658-677.

Newton, P., Glackin, S., \& Meyer, D. (2017). Becoming urban: Exploring the capacity for a suburban-to-urban transition in Australia's low density cities. Sustainability, 9(10), 1718. https://doi.org/10.3390/su9101718

Newton, P., Glackin, S., Witheridge, J., \& Garner, L. (2020). Beyond small lot subdivision: Pathways for municipality-initiated and resident-supported precinct-scale medium-density residential infill regeneration in greyfield suburbs. Urban Policy and Research, 38(4), 338-356. https://doi.org/10.108 0/08111146.2020.1815186

NSW Government Architect. (2021). Better placed. https://www.governmentarchitect.nsw.gov.au/policies/better-placed 
OECD. (2012). Compact city policies: A comparative assessment. OECD Publishing. https://doi.org/10.1787/9789264167865-en

OECD. (2018). Rethinking urban sprawl: Moving towards sustainable cities. OECD Publishing.

Parolek, D. (2019). What is missing middle housing? https://missingmiddlehousing.com/about

PCA. (2020). Principles of successful precincts. Property Council of Australia.

Place Design Group. (2019). Downsizer housing and why Doris is pissed. Retrieved November 20, 2020, from https://placedesigngroup.com/news-updates/ the-doris-index/

Spencer, A., Gill, J., \& Schmahmann, L. (2015). Urban or suburban? Examining the density of Australian cities in a global context. State of Australian Cities Conference, Gold Coast, QLD.

The Lancet. (2016, September 23). Special issue: Urban design, transport, and health. 388(10062).

Thomson, G., \& Newman, P. (2016). Geoengineering in the Anthropocene through regenerative urbanism. Geosciences, 6(4), 46. https://doi.org/10.3390/ geosciences 6040046

Thomson, G., \& Newman, P. (2018). Urban fabrics and urban metabolism: From sustainable to regenerative cities. Resources, Conservation and Recycling, 132, 218-229. https://doi.org/10.1016/j.resconrec.2017.01.010

Thomson, G., \& Newman, P. (2020). Cities and the Anthropocene: Urban governance for the new era of regenerative cities. Urban Studies, 57(7), 1502-1151.

Thomson, G., Newton, P., \& Newman, P. (2016). Urban regeneration and urban fabrics in Australian cities. Journal of Urban Regeneration and Renewal, 10(2), 1-22.

Trubka, R., Newman, P., \& Bilsborough, D. (2010). The cost of urban sprawl: Infrastructure and transportation. Environment Design Guide, 83, 1-6.

UrbiumEtOrbi. (2015, July 10). Relation between building typologies \& density. https://urbiumetorbi.wordpress.com/2015/07/10/building-typologies-anddensity-by-richard-rogers/comment-page-1/?unapproved=79\&moderationhash $=29 \mathrm{~d} 35$ ef5 $4 \mathrm{~d} 4 \mathrm{f} 47 \mathrm{fa} 0955$ bebf27427418\#comment-79

Venice Biennale. (2012). https://www.archdaily.com/268435/venice-biennale2012-spontaneous-interventions-usa-pavilion 
Weller, R. (2019). What ever happened to (Australian) urbanism? Retrieved November 15, 2020, from https://landscapeaustralia.com/articles/whathappened-to-australian-urbanism/

Woodcock, I., Dovey, K., Wollan, S., \& Beyerle, A. (2010). Modelling the compact city: Capacities and visions for Melbourne. Australian Planner, 47(2), 94-104.

Open Access This chapter is licensed under the terms of the Creative Commons Attribution 4.0 International License (http://creativecommons.org/licenses/ by/4.0/), which permits use, sharing, adaptation, distribution and reproduction in any medium or format, as long as you give appropriate credit to the original author(s) and the source, provide a link to the Creative Commons licence and indicate if changes were made.

The images or other third party material in this chapter are included in the chapter's Creative Commons licence, unless indicated otherwise in a credit line to the material. If material is not included in the chapter's Creative Commons licence and your intended use is not permitted by statutory regulation or exceeds the permitted use, you will need to obtain permission directly from the copyright holder.

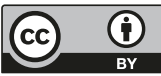

